\title{
EL PROYECTO DE ANTONIO TOVAR DE UNA EXPOSICIÓN DE CANARIAS EN 1941 Y LA CONSOLIDACIÓN DE LAS COMISARÍAS INSULARES DE EXCAVACIONES COMO RESPUESTA AL INTENTO DE HITLER DE ANEXIONARSE UNA ISLA CANARIA
}

\author{
THE PROJECT OF ANTONIO TOVAR FOR AN EXHIBITION IN THE CANARY ISLANDS IN 1941 AND \\ THE CONSOLIDATION OF THE ISLANDS COMMISSARIAT FOR ARCHAEOLOGICAL EXCAVATIONS \\ AS A RESPONSE TO HITLER'S ATTEMPT TO ANNEX A CANARY ISLAND
}

ALFREDO MEDEROS MARTÍN

Universidad Autónoma de Madrid

\section{ANTONIO TOVAR, EL TEÓRICO DEL PROYEC- TO IMPERIAL ESPAÑOL Y SU LEBENSRAUM}

Antonio Tovar Llorente realizó estudios de Filosofía y Letras y Derecho en la Universidad de Valladolid a partir de 1931 y posteriormente los cursos de doctorado en la Universidad de Madrid. Volvió de París en marzo de 1936 para leer su tesis doctoral en la Universidad de Madrid, pero no pudo hacerlo por las huelgas y se marchó a Berlín esa primavera. Residente en Berlín en la Hegelhaus, evolucionó hacia posiciones nacionalsocialistas, reuniéndose diariamente con el sector de los estudiantes españoles partidarios del alzamiento en el café Wien (Tovar, 1986, 14).

Desde Berlín, regresó a España con Martín Almagro Basch a finales de agosto de 1936, ambos con una camisa azul y un correaje de piel que le habían dado los nacionalsocialistas en Alemania. Una vez en Valladolid, contactó con un amigo de su época de estudiante, José Villanueva de la Peña, Jefe de Prensa y Propaganda de Falange Española en Valladolid, quien le puso en contacto con el hermano de Onésimo Redondo, Jefe provincial de Falange Española en Valladolid (Tovar, 1986, 14-15), que procedía del sector más radical aglutinado primero en la Juntas de Ofensiva Nacional Sindicalista -J.O.N.S.-, quien le encargó de Radio Valladolid, la primera emisora de radio de Falange Española. Allí se ganó el prestigio de los falangistas ortodoxos «por su valerosa conducta cuando en febrero, contra las consignas oficiales del pre-franquismo, logró que el último discurso de José Antonio fuese difundido por la radio vallisoletana» (Laín, 1976, 207).

La necesidad de un territorio o espacio vital español, lebensraum, es planteada por Tovar en su texto El Imperio de España de octubre de 1936, que reeditó después en la revista Falange Española en 1937, ya firmándolo, y posteriormente como monografía en La Habana de Cuba en 1938 y en España en 1941, donde defiende que «El pueblo español, que ha tenido durante toda su historia (...) la vocación y el ansia de Imperio
(...) para imponerle creencias y modos españoles» (Tovar, 1936/1941, 10). Frente al nuevo Imperio, serán «Amigos y enemigos nuestros, todos los países no hispánicos de Europa y del mundo. Amigos, en cuanto acepten nuestras futuras $-\mathrm{y}$ pasadas- dimensiones imperiales; enemigos, en cuanto las rechacen» (Tovar, 1936/1941, 12). Los nuevos territorios eran irrenunciables pues «nuestra idea imperial, esencialmente española (...) no puede olvidarse de las dimensiones de la gran España» (Tovar, 1936/1941, 13), y «la sola conciencia de los deberes del Imperio será bastante para mantener la idea de la unidad de destino» (Tovar, 1936/1941, 15). Los nuevos poderes habrán de ser «el fascismo italiano, el nacional-socialismo alemán y el nuevo Estado de España y Portugal, el suelo todo del Imperio de Carlos V» (Tovar, 1936/1941, 76).

En este nuevo Imperio los judíos ya habían sido expulsados, «la España de 1500 (...) ha logrado suprimir el problema judío (...) El judío era peligroso como representante de una religión - de una cultura- radicalmente distinta, antieuropea, antinacional, anticristiana. Bastaba con que el judío abandonase esta base religiosa para que en unos años o en unos siglos (...) quedase asimilado y confundido», pues para «el español, en que la raza no lo es todo, el problema semita pierde virulencia y no resulta algo fatal y de sangre» (Tovar, 1936/1941, 55).

La difusión por Radio Valladolid el 2 de febrero de 1937 del discurso que José Antonio Primo de Rivera había pronunciado un año antes en Madrid, donde se criticaba a la Confederación Españolas de Derechas Autónomas y se propugnaba como «alta tarea moral», «desmontar el capitalismo», acabó con la detención temporal de Antonio Tovar, José Antonio Girón y Javier Martínez de Bedoya durante una semana y orden de detención contra Víctor de la Serna (Rodríguez Jiménez, 2000, 272-274). Movilizado, recibió instrucción militar y fue enviado al frente de Madrid.

Luego se integró en la Delegación Nacional de Prensa y Propaganda de Falange Española en mayo de 1937, reclamado por Ridruejo, para pasar después 
a la Jefatura de los Servicios de Radio de Prensa y Propaganda de Falange Española desde noviembre de 1937, bajo las órdenes de Serrano Suñer, y acabar siendo miembro del I Consejo Nacional y la Junta Política de Falange Española Tradicionalista y de las J.O.N.S.

Al ocupar Serrano Suñer en enero de 1938 el Ministerio de Gobernación y el de Delegado Nacional del Servicio de Prensa y Propaganda, Dionisio Ridruejo fue nombrado Director General de Propaganda en marzo de 1938, instalándose en el Palacio de la Audiencia en Burgos, asignando a Tovar en Radiodifusión y Director de Radio Nacional. En otoño de 1938 asistió al Congreso del Partido Nacionalsocialista en Nuremberg, en una delegación que encabezaba el general Espinosa de los Monteros, donde Hitler anunció su amenaza de anexión contra Checoslovaquia.

Tras el final de la Guerra Civil, primero fue designado miembro del II Consejo Nacional de Falange Española Tradicionalista y de las J.O.N.S. desde el 9 de septiembre de 1939, y luego Director General de Enseñanzas Profesionales y Técnicas en octubre de 1939, para cubrir las apariencias con el falangismo ortodoxo, pues se concedió el Ministerio de Educación al católico Ibáñez Martín.

En septiembre de 1939 pronunció unas conferencias en Barcelona que incluyó en la reedición en 1941 de El Imperio de España. Por entonces, ya estallada la Segunda Guerra Mundial, señalaba que «El viejo estilo imperial de Viena es el que va imponiéndose en la idea de Hitler sobre Europa central. Aparece definiéndose ya un nuevo orden que tiene mucho de antiguo y que, como aquél, se funda en el principio de que hay pueblos hechos para mandar y pueblos hechos para obedecer. Los españoles tenemos la fortuna de pertenecer a un pueblo hecho para mandar. Quien nos enseña esto es nuestra historia. Y nuestro deber es, entonces, potenciar en lo actual toda nuestra historia, actualizarla, movilizarla agresivamente con estilo ofensivo y de acción directa. Sólo de esa manera España llegará a ser una de las cuatro, cinco o seis grandes unidades que -José Antonio presintió esto- están llamadas a gobernar el mundo de este siglo» (Tovar, 1941, 106-107).

Conquistada parcialmente Francia, España se declaró el 12 de junio de 1940, «no beligerante», dejando de ser neutral, y después de un acuerdo con el Ministerio de Asuntos Exteriores francés el día 13, se ordenó la mañana del 14 la ocupación de Tánger (Goda, 1998/2002, 108-109).

El día 16 de junio el general Juan Vigón, jefe del Alto Estado Mayor, le entregó a Hitler una carta del general Franco. Los detalles los precisó el Ministro de Asuntos Exteriores, Juan Beigbeder, al embajador alemán en Madrid, Eberhard von Stohrer, el día 19 de junio, y simultáneamente su contenido iba en sendas cartas que entregaron los embajadores de España en Berlín y Roma. En las mismas se precisaban las condiciones de España para entrar en guerra contra el Reino Unido a cambio de Gibraltar, todo el Marruecos francés, la región de Orán en Argelia, el avance del Sahara español hasta el paralelo $20^{\circ}$ Norte, que se usaba para separar Libia del Sudán, y la ampliación de la Guinea española en detrimento de la antigua colonia alemana del Camerún, apoyándose en el tratado de El Pardo con Portugal de 1788. Sin embargo, Berlín consideró estas reivindicaciones excesivas y retrasó su contestación (Goda, 1998/2002, 112-113). Apenas pocos días después, el ejército alemán alcanzó la frontera con España el 26 de junio.

Al mes siguiente, una conferencia de Tovar en el Ibero-Amerikanisches Institut Preussischer Kulturbesitz - Instituto Ibero-Americano de Patrimonio Cultural Prusiano- de Berlín, el 11 de julio de 1940, señalaba que «en el umbral de una nueva era, abierta por las hazañas de los ejércitos germanos. Nos encontramos en los últimos días de la vieja Europa que fue responsable de la decadencia de España y creemos que ahora suena la hora de la decisión, para la cual debemos encontrarnos preparados» (Bowen, 2000, 86). Ya había señalado que «nuestros enemigos hoy son también los de ayer: los que, después de vernos caídos, después de habernos aniquilado como potencia mundial y habernos hecho perder dimensiones de Imperio, y después de quitarnos a fuerza de fatiga voluntad y nuestra fe en los destinos de España, nos tienden la mano falsa de la curiosidad turística» (Tovar, 1936/1941, 12).

No obstante, en una reunión de Hitler con el almirante Erich Raeder, ese mismo día 11 de junio, ya le señaló como prioritario conseguir la cesión por España de una de las Islas Canarias a cambio del Marruecos francés, donde también deseaba instalar algunas bases militares en puertos marroquíes. Esta propuesta está recogida en la propuesta de negociación alemana con España que se preparó a finales de agosto, aunque no se informó de ello al embajador alemán en Madrid para no crear fricciones, la cual también rechazaba las peticiones españolas en Guinea, e incluso pretendía anexionarse también la isla de Fernando Poo (Goda, 1998/2002, 116, 120-121).

La situación geoestratégica se aclaró el 3 de septiembre, con la publicación del Acuerdo de Bases para Destructores del Reino Unido con los Estados Unidos, por el que se les permitía a los norteamericanos utilizar 8 bases marítimas desde la Guayana británica hasta la isla de Terranova -Newfoundland-, junto a Labrador, la base americana más próxima a Europa de los británicos. El acuerdo hizo declarar a Hitler el 5 de septiembre que tendría que tomar las islas Canarias, Azores y Cabo Verde antes que fueran ocupadas por Estados Unidos o el Reino Unido (Goda, 1998/2002, 124).

Entre el 12 y el 19 de septiembre de 1940, Tovar acompañó a Serrano Suñer en la primera visita a nivel gubernamental a Berlín. En la entrevista del día 16 con el Ministro de Asuntos Exteriores alemán, Joachim von Ribbentrop insistió en la cesión de una de las Islas Canarias para convertirla en base aérea y naval, a lo que se negó terminantemente Serrano Suñer. 
En sus primeras memorias, el tema de Canarias queda elusivo y sólo se comenta la cesión de una base en Canarias, en «esta primera conversación (...) Atravesó por momentos de verdadera incomodidad ante la insistencia del Ministro alemán en una petición impertinente» (Serrano Suñer, 1973, 265). Pero años después el propio Serrano Suñer añadió más detalles, ya eran varias bases militares, «la cesión de bases en Canarias (...) al escuchar yo estas peticiones, me puse en pie (...) para regresar a España cortando las conversaciones que sólo continuaron al retirar expresamente el Ministro alemán aquella petición que un español, por amigo que fuera, no podía oír» (Serrano Suñer, 1977, 296).

Describe esta conversación con cierta concreción, «Un día hablamos en su casa donde un gran mapa de África colgado en la pared nos presidía (...) El Ministro alemán me pidió la cesión a Alemania de una base militar en las Canarias. Aquel golpe me cogía desprevenido y sólo pude reaccionar rechazándolo de plano». Sin embargo, «Comunes necesidades de la defensa europeoafricana frente al imperialismo americano -me replicó- así lo exigen. Espero que el Generalísimo lo comprenda así». «El diálogo había alcanzado un punto de máxima incomodidad. El insistió fundadamente en el gran peligro que corrían las islas de Occidente (...) Si los americanos llegan a poner un pie en ellas será demasiado tarde» (Serrano Suñer, 1973, 275-276).

La petición no era sólo de una base aeronaval, sino de toda una isla, como se comprueba en la documentación original, sugiriendo Goda $(1998 / 2002,133)$ la isla de Gran Canaria que tenía las mejores instalaciones aeroportuarias. Además, solicitaban instalar bases militares en Mogador y Agadir, lo que obligó a Serrano Suñer a escribir ese mismo día al general Franco, llevando Tomás García Figueras el mensaje por avión (Ros Agudo, 2008, 228-229). Franco tampoco estaba de acuerdo con presencia de bases alemanas en el territorio de Marruecos, que consideraba territorio exclusivo, «innecesarias en tiempo de paz y superfluas en tiempo de guerra», como le señaló por carta el 18 de diciembre (Ros Agudo, 2008, 234-235).

El día 17 se entrevistaron Serrano Suñer y Tovar con Hitler en la Cancillería, negándole los alemanes autorización a participar al embajador de España, Espinosa de los Monteros (Serrano Suñer, 1977, 291). El general Espinosa de los Monteros, tenía un buen nivel de alemán, porque su padre había sido agregado militar en la embajada de España en Viena y su hermano embajador de España en Berlín entre 1926-31, pero Serrano Suñer y los alemanes prefirieron contar sólo con Tovar.

En la entrevista con Hitler, éste indicó que debía «preverse la posibilidad de que si la lucha actual se prolongara se convirtiera en una guerra entre el continente europeo y el americano», «tomando medidas sobre un compás sobre un mapa del Atlántico y calculando distancias en relación el radio o autonomía de los stukas» (Serrano Suñer, 1973, 272, 275).
Una vez derrotada Francia, el objetivo de Hitler era tener el control de una de las Islas Canarias para poder disponer de bases aéreas y marinas antes de enfrentarse a Estados Unidos y tratar de controlar completamente el hemisferio norte como ha planteado correctamente Goda (1998/2002, 155-156), a cambio de lo cual estaba dispuesto a ceder el Marruecos francés.

Después de la entrevista con Hitler, hubo una segunda entrevista con Ribbentrop ese mismo día 17, allí «Ribbentrop aseguró que Alemania obtendría de Francia su zona de Marruecos en el tratado de paz y que se la entregaría a España, con la excepción de las bases de Agadir y Mogador (...) preguntó a Serrano si España estaba dispuesta a ceder a Alemania una de las Canarias», lo que fue rechazado por Serrano Suñer que sugirió como alternativa para los alemanes la isla de Madeira y San Luis de Senegal. Otra opción que le ofreció Ribbentrop era que Alemania estaba dispuesta a quedarse con la Guinea española y Fernando Poo, a cambio del Marruecos francés, también rechazado por Serrano Suñer (Goda, 1998/2002, 134; Ros Agudo, 2008, 231-232). Al día siguiente, el 18, en una carta de Hitler al general Franco, se planteaba de manera más matizada la petición, insistiendo que la caída de Gibraltar provocaría la toma por los británicos en una o varias de las Islas Canarias, por lo que le pedía poder instalar aviones de largo alcance y bombarderos submarinos alemanes en Las Palmas de Gran Canaria (Goda, 1998/2002, 135).

Después de visitar el frente francés, Serrano Suñer y Tovar regresaron a Berlín el 22, entrevistándose de nuevo con Ribbentrop el 24 de septiembre y con Hitler al día siguiente. En la primera entrevista, Ribbentrop volvió a solicitar la cesión de una de las Canarias, a lo que Serrano contestó que no estaba autorizado a plantearle esta cuestión al general Franco, por lo que Ribbentrop optó por reclamar la Guinea española y la isla de Fernando Poo, que también fue rechazado por Serrano, quien tampoco aceptó la presencia de bases alemanas en Mogador y Agadir (Goda, 1998/2002, 149). El día 25 Hitler insistió en la necesidad de «establecer bases alemanas en las islas situadas al oeste de África», protegiendo desde Canarias a las islas de Cabo Verde y las Azores (Ros Agudo, 2008, 238), y ante las permanentes reticencias de Serrano, que se excusaba en no tener capacidad para decidir, Hitler planteó la necesidad de tratar directamente el problema de Marruecos y Canarias con el general Franco (Goda, 1998/2002, 152). Antes de marcharse de Berlín el 27 , ese mismo día 25, Serrano planteó al embajador alemán en Madrid, von Stohrer, las únicas posibles concesiones, renuncia a ampliar el territorio de la Guinea española a costa del antiguo Camerún alemán y enormes concesiones mineras en Marruecos y España que serían quitadas a empresas francesas e inglesas (Goda, 1998/2002, 151). El día de la marcha de Serrano se firmaba en Berlín el Pacto Tripartito entre Alemania, Italia y Japón frente a una posible agresión norteamericana. 
Las razones de la discrepancia son obvias, el general Franco, al apoyar la toma alemana de Gibraltar, permitía expulsar a los británicos del Mediterráneo Occidental y tener el control de su acceso, apoyando con 120.000 soldados españoles en Marruecos y 30.000 en las Islas Canarias. En cambio, el objetivo de Hitler era a medio plazo, para preparar el conflicto con Estados Unidos como plantea Goda (1998/2002, 155156), tratando también de evitar un futuro desembarco como al final sucedió, y para ello precisaba instalar sus tropas en bases de Marruecos y Canarias, lo que no estaba dispuesto a admitir el general Franco, que consideraba ambos territorios parte exclusiva del futuro Imperio español.

En todo caso, el éxito de este viaje, que convirtió a Serrano Suñer en el interlocutor español con Hitler, supuso su nombramiento el 16 de octubre como Ministro de Asuntos Exteriores. Paralelamente, Tovar fue nombrado Subsecretario de Prensa y Propaganda del Ministerio de Gobernación.

En esta entrevista, como reconoce Serrano Suñer (1977, 284, 288), «España se adhirió en Hendaya al 'Pacto Tripartito' que era la alianza militar», pues «tanto Franco como yo creíamos entonces en la gran probabilidad -en la seguridad-de la victoria alemana, cuando menos en el Continente, donde suponíamos que el III Reich era invulnerable». En el Protocolo firmado, «España declara estar dispuesta a acceder a la conclusión del Pacto Tripartito en septiembre 27, 1940 entre Italia, Alemania y Japón, y a este fin firmar, en la fecha que sea fijada por las cuatro Potencias unidas, un protocolo apropiado que contemple su actual acceso. Por el presente Protocolo, España declara su conformidad al Tratado de Amistad y Alianza entre Italia y Alemania y al mencionado Protocolo Secreto complementario de 22 de mayo de 1939» (Serrano Suñer, 1977, 312).

En Hendaya, Hitler, «Por lo que se refiere a las Islas canarias manifestó que (...) los Estados Unidos (...) en cualquier golpe de mano podrían hacerse con ellas y sería, desde luego, un golpe muy fuerte contra la campaña submarina» (Serrano Suñer, 1977, 294), No obstante, después de la firma del Protocolo, en la reunión de Hitler y Ribbentrop con Mussolini y Ciano el 28 de octubre en Florencia, Hitler dio por hecho que conseguiría las bases militares en Marruecos, «aunque señaló con nostalgia que él hubiera preferido una de las islas» (Goda, 1998/2002, 180). Los planes ya estaban previamente hechos pues, desde el 5 de septiembre de 1940, Hitler había ordenado la planificación de la ocupación de las islas de Canarias, Cabo Verde y Azores (Goda, 1998/2002, 188).

Tovar no sólo era el intérprete de alemán en las visitas a Berlín de Serrano Suñer, sino que también participó en Hendaya (Serrano Suñer, 1977, 289), aunque por el restringido protocolo no pudo asistir a la entrevista principal, sustituido por el Barón de las Torres, Jefe de Protocolo del Ministerio de Asuntos Exteriores (Serrano Suñer, 1977, 291). Sin embargo, al acabar la entrevista y regresar en el tren, «Franco (...) sentado junto a la pequeña mesa del break conmigo, llamó al barón de las Torres y le preguntó qué le había parecido aquello (...) Con el, y con el profesor Tovar, fuimos hablando del tema y, absorbidos (...) llegamos a Pasajes» (Serrano Suñer, 1977, 300), lo que es indicativo del nivel de absoluta confianza que gozaba tanto por parte de Serrano Suñer, como por parte del general Franco.

No obstante, aún más importante, es que fue Tovar quien redactó después de Hendaya la carta donde Franco reclamaba a Hitler sus reivindicaciones territoriales sobre el imperio colonial francés en África (Tusell, 1995, 164, 214).

En cambio, Hitler sólo ofrecía Gibraltar a España, a cambio de la isla canaria si había una paz de compromiso con Inglaterra, y en caso de derrota militar inglesa las cesiones se ampliaban al Marruecos francés, el Oranesado, el incremento de la Guinea española, y se compensaba a la Francia de Vichy con Nigeria en manos británicas (Goda, 1998/2002, 163; Ros Agudo, 2008, 224).

Comprometida una futura intervención española en la guerra, que firmó Franco en el Protocolo secreto, quedaba sin precisarse la fecha de entrada en la guerra de España con las potencias del Eje. Para fijar esta fecha, Hitler organizó una entrevista con Serrano Suñer en Berghof (Obersalzberg, Baviera, Alemania), su retiro en los Alpes bávaros, donde había residido desde 1924, reunión aceptada por Serrano Suñer el día 12. Una vez confirmado el encuentro, Hitler firmó la directiva de guerra $\mathrm{n}^{\circ} 18$ que planificaba la invasión de Gibraltar y el traslado de tropas alemanas a las Islas Canarias, las Islas Azores y al Marruecos francés y español. El contenido de la directiva se lo comunicó a Serrano Suñer el 18 de noviembre de 1940, acompañado por Tovar y el Barón de las Torres (Serrano Suñer, 1973, 325). Serrano Suñer se encontró con un plan cuyo resultado final, salvo el aspecto positivo de la toma de Gibraltar, suponía la instalación de contingentes militares alemanes en Marruecos. La primera respuesta del general Franco fue declarar la unidad entre el Protectorado español y Tánger, anexionándoselo el 23 de noviembre.

«Hitler concedía - no sin razón- grandísima importancia a que las islas Canarias estuvieran perfectamente fortificadas y defendidas para evitar un desembarco inglés. Le contesté diciendo que podía darle la seguridad de que las islas Canarias tenían tanto en mandos como en soldados lo mejor y más escogido del ejército español, habiéndose fortificado especialmente Gran Canaria (...) Hitler escuchaba como queriendo quitar valor a los elementos de que yo hablaba y me interrumpió así: 'Hay que poner antiaéreos en los aeródromos de Canarias y hay que llevar allí los stukas que es la única manera de alejar de allí definitivamente toda escuadra enemiga' (...) y siguió hablando: Tenemos hoy aviones de 4.000 kilómetros de radio de acción, es decir, 4.000 de ida y otros tantos de vuelta, que desde 
Canarias estarían en condiciones de poder cortar el tráfico marítimo con el África del Sur» (Serrano Suñer, 1973, 332-333).

En todo caso, debe advertirse que finalmente, «después de las dos reuniones de Serrano en Berlín, el caudillo escribió a Hitler para decirle que Alemania podría utilizar las bases españolas en Canarias durante la guerra» (Goda, 1998/2002, 213). Y el 28 de septiembre, en la entrevista de Hitler con Mussolini, «le comunicó su deseo de instalar allí bombarderos submarinos, artillería de largo alcance y miembros de los cuerpos especiales» (Goda, 1998/2002, 214).

Sin embargo, el fracaso de las tropas de Mussolini en Grecia y posteriormente en el Norte de África, advirtió a Franco y Vigón de los riesgos de la guerra para un país con un ejército no bien preparado, cuando se seguía sin tener ninguna garantía por escrito de las reclamaciones territoriales en Marruecos y Orán. El 7 de diciembre, Franco, acompañado por el general Juan Vigón, jefe del Alto Estado Mayor, rechazó la petición expresa de Hitler de entrar en guerra el 10 de enero de 1941, para poder permitir el paso de tropas alemanas destinadas a conquistar Gibraltar, propuesta que le trasmitió en entrevista el Almirante Wilhelm Canaris (Goda, 1998/2002, 206-207), el cual se había desplazado a Madrid desde el día 4. La reunión entre Franco y Mussolini en Bordighera, el 12 de febrero de 1941, mostró de nuevo fricciones entre españoles e italianos sobre el destino del imperio colonial francés, al no estar Franco dispuesto a renunciar a las demandas territoriales de España en África, para lo cual seguía manteniendo 7 divisiones en el Protectorado español de Marruecos.

Joachim von Ribbentrop reconoció la imposibilidad de convencer de momento al general Franco, cuando ordenó el 22 de febrero a su embajador en Madrid, Eberhard von Storher, no seguir insistiendo a Franco de entrar en guerra (Bowen, 2000, 96-97).

No obstante, Tovar, miembro del grupo de partidarios de un claro alineamiento con Alemania, señalaba en una conferencia el 23 de marzo de 1941, recogida por la prensa, que «España, por proclamar y defender una fórmula política nueva, vio ensangrentado su suelo por los horrores de una guerra civil» y ese «sacrificio no puede carecer de recompensa» por parte de Alemania.

Las ambiciones de Serrano Suñer comenzaron a preocupar al general Franco seriamente cuando fueron defendidas por las potencias del Eje, las cuales le sugirieron que se reservase la jefatura del Estado y del ejército, para ceder la presidencia del gobierno a Serrano Suñer, quien así podría ejercer una dictadura de partido a través de Falange Española. Por ello, el 5 de mayo de 1941 decidió una remodelación del gobierno donde los militares tomaron posiciones frente a los falangistas partidarios de Alemania (Rodríguez Jiménez, 2000, 356-357). El Coronel Valentín Galarza fue nombrado Ministro de Gobernación, cargo que estaba vacante desde el nombramiento de Serrano Suñer como
Ministro de Asuntos Exteriores, y la Subsecretaría de Presidencia del Gobierno pasó al capitán de navío Luis Carrero Blanco.

Tras el cese en la Secretaría Política de Gobernación de Finat, Conde de Mayalde, las críticas negativas de los falangistas desde el diario Arriba acabaron con el cese de Tovar de la Subsecretaría de Prensa y Propaganda y de Ridruejo de la Dirección General de Propaganda y la dimisión de Miguel Primo de Rivera del Gobierno Civil de Madrid. También se cesó al Vicesecretario General de Falange y Ministro sin cartera, amigo de Serrano Suñer, Pedro Gamero del Castillo, que fue sustituido por José Luna Meléndez y se nombró un nuevo Secretario General de Falange, José Luis Arrese, mientras para compensar se ascendió a Miguel Primo de Rivera a Ministro de Agricultura.

\section{LA ORGANIZACIÓN DE LA EXPOSICIÓN DE LAS ISLAS CANARIAS EN 1941 POR TOVAR Y RIDRUEJO}

Teniendo presente que la principal reivindicación alemana había sido una isla de Canarias para disponer de una gran base aérea y marítima tanto en las reuniones entre Serrano Suñer con Ribbentrop en Berlín el 16, 17 y 24 de septiembre de 1940, actuando como traductor Tovar, como en la entrevista del general Franco con Hitler en Hendaya el 23 de octubre, donde también asistieron Tovar y Serrano Suñer, aunque no en el vagón de la entrevista, poco puede sorprender la orden emitida el 18 de febrero de 1941, que indicaba la prioridad que se debía dar a las Islas Canarias como una parte integrante de España y del futuro Imperio español.

«Con esta fecha ha sido firmada por el Excmo. Sr. Ministro Presidente de la Junta Política y Delegado Nacional de Prensa y Propaganda de F.E.T. y de las J.O.N.S. [Serrano Suñer], la autorización para celebrar en Madrid una Exposición del Archipiélago Canario (...) Por Dios, España y su Revolución Nacional-sindicalista (...) El Subsecretario de Prensa y Propaganda, Antonio Tovar» (ASO, 20-2-41). La dirección fue encomendada al pintor y cartelista guipuzcoano Juan Cabanas Erauski, entonces Jefe de Ceremonial de Falange Española.

En el diario de Pérez de Barradas (FD2005/1/20, 45) se indica el día 20 de febrero que había un plan para organizar tres exposiciones sucesivas, primero Canarias, luego Marruecos y Colonias y después Baleares, enfatizando la españolidad de los territorios insulares y norteafricanos, encargándose Martínez Santa-Olalla de la arqueología y Pérez de Barradas de la Etnología y Folklore.

A los pocos días, el 26 de febrero, Martínez Santa-Olalla propuso al director de la exposición una cabalgata inaugural de la exposición, donde figurarían «grupos, comparsas y carrozas, coros de cantores, grupos de baile, cuadro de la lucha canaria, etc.» que 
sería filmada y proyectada en los cines españoles, idea aceptada por Cabanas $(1941,8)$ que la consideró el «heraldo de la Exposición», enfatizando que «Artísticamente se plantea un problema nuevo, puesto que esta Exposición ambulante, que sería la Cabalgata, no tiene precedentes en España».

Realmente las competencias de Martínez SantaOlalla eran mayores y se le encargó de la Sección de Historia, que tendría una sala de $19 \times 10 \mathrm{~m}$. Para la misma, ese mismo día 26, planteaba sus prioridades, «presentar plásticamente la unidad étnica y cultural del Archipiélago Canario con la Península hispánica y el África español (...) y sobre todo el carácter de bastión hispánico que resiste los embates de Inglaterra y Holanda».

Respecto a la prehistoria e historia, «dos grandes mapas murales; uno resume las culturas y expansión étnica de la España prehistórica en tierras afroeuropeas, y, por tanto, la integración plena y rigurosa de Canarias en la más vieja hispanidad. El otro gran mapa mural ha de ofrecer cuales son las relaciones y momentos culturales de Canarias en íntima dependencia con el sur peninsular y el África español».

En la parte expositiva sobre la prehistoria, «El primer tercio de la Sala llevará dos grandes dioramas representando el uno una cueva sepulcral guanche y tinerfeña con sus momias y ajuar consiguiente a base de un grabado del siglo XVII. El otro gran diorama situado enfrente representará un Tagorero o cabildo guanche de Gran Canaria, también con figura de tamaño natural y un fondo de poblado guanche» (ASO, 26-2-1941), que posteriormente modificó colocando de fondo el poblado de cuevas artificiales de Cuatro Puertas de Telde (Arriba, 17-6-41).

Para anunciar y preparar cuanto antes la exposición se organizó un viaje a las Islas Canarias en el que participaron Dionisio Ridruejo, Director General de Propaganda; Juan Cabanas, Director de la exposición; su administrador, Allué; el arquitecto de la Delegación Nacional de Prensa y Propaganda de Falange, Avelino Aróztegui Bastoure; el fotógrafo, Augusto Valmitjana, Jefe de Ceremonial y Plástica de la Vicesecretaría de Educación Nacional; el responsable de la Sala de Artesanía, Miguel Moreno Borondo, también vasco de San Sebastián, entonces Jefe de la Exposición del Servicio de Artesanía hasta que entró ese año de 1941 en el Cuerpo Nacional de Inspectores de Trabajo; el de la Sala de Agricultura e Industria, Francisco Alonso Luengo, Jefe del Negociado de Canarias en el Ministerio de Industria y Comercio, con su mujer; el de la sala de Historia, Martínez Santa-Olalla, y el de la Sala de Folklore, Pérez de Barradas (FD2005/1/20, 55-86), que lo recoge en su diario.

Partieron de Cádiz el 7 de marzo y llegaron a Tenerife la tarde del día 10 , sin embargo, «ni formación ni banderas para que Dionisio y Cabanas se pongan el uniforme blanco», instalándose en el hotel Orotava. En Tenerife, Martínez Santa-Olalla, Pérez de Barradas y Reyna se escaparon del grupo oficial, primero a comprar libros y luego a visitar La Laguna, donde se encontraron con Dacio Darias y Padrón. Desde allí se desplazaron al valle de la Orotava para ver el Teide al atardecer.

Por la mañana temprano del día 8 partieron para Las Palmas de Gran Canaria, donde llegaron a las 7.30 a.m., también sin «nadie en el muelle», hasta que a las 9 a.m. aparecieron las autoridades, instalándose en el hotel Negresco. El día 12 comenzaron las visitas a yacimientos arqueológicos, llevados por Jiménez Sánchez, donde la prioridad fue la toma de fotografías por Valmitjana para la exposición, pero que permitió visitar el yacimiento de Cuatro Puertas a Martínez SantaOlalla y Pérez de Barradas, y el día 13 el Cenobio de Valerón (Guía) y los túmulos y casas de Agaete, dejando ambos a Jiménez Sánchez «con plenos poderes», el día 14, para los preparativos de la exposición. El día 15 por la mañana regresaron a Tenerife, visitando el Museo Municipal de Tenerife, cuya colección consideró Pérez de Barradas «pobre», e intentaron conseguir para la exposición «vasos de Fuerteventura con decorado inciso tipo Almería y otros de Gomera de madera», pero su director se opuso a su traslado a Madrid. Esa tarde se desplazaron con Darias y Padrón de nuevo a La Orotava, embarcándose por la noche para regresar a Cádiz donde llegaron el día 18. En el trayecto de vuelta, uno de los libros que había comprado y leyó Pérez de Barradas fue las Antigüedades de las Islas Afortunadas de Viana (1604).

El aspecto más notable desde un punto de vista arqueológico es que se reforzó el lazo entre Martínez Santa-Olalla y sus dos Comisarios Provinciales, Jiménez Sánchez y Darias y Padrón, con quienes desde entonces comenzó a colaborar estrechamente.

La exposición quedó definida en un borrador de Cabanas, la cual se celebraría durante un mes entre el 15 de mayo y el 15 de junio de 1941, aunque en el texto se aprecia que inicialmente se pensó incluso del 1 al 30 de mayo. Para la inauguración se pensaba que estuviesen presentes un representante de cada Jefatura Provincial de Prensa y Propaganda de toda España.

Las secciones o salas debían ser siete, 1) Intervención de las Islas Canarias en el Glorioso Alzamiento, 2) Turismo, 3) Artesanía, 4) Agricultura e industria, 5) Folklore, 6) Historia (Gráfica de Canarias) y 7) Arte (Arquitectura, pintura, escultura y grabado).

El aspecto más resaltado era el propagandístico, pues era un proyecto de Ridruejo, Director General de Propaganda, siguiendo los consejos de Serrano Suñer y Tovar. En este sentido se preveía series de artículos en prensa, debiendo entregar cada jefe de sala cinco artículos diferentes referentes al tema de la sala que serían distribuidos en la prensa nacional. Conferencias en la radio, acompañadas de conciertos, cantos o «interviús» con personalidades canarias. Diapositivas anunciadoras de la exposición. Concurso de carteles inspirados en Canarias, aspecto de especial interés para su director, Cabanas. Sellos de correos anunciadores de la exposición que durarían durante el mes de la misma. Folletos explicativos, siendo el primero el 
correspondiente a la propia planificación de la Exposición de las Islas Canarias, Madrid-1941, Delegación Nacional de Prensa y Propaganda de F.E.T. y de las J.O.N.S. (Cabanas, 1941). Tres tipos de películas documentales, uno dedicado a la agricultura e industria, otro al turismo y el tercero al folklore.

Se planificaron ciclos de conferencias sobre los siete temas que abarcaba la exposición, con tres personalidades para cada tema, las cuales podrían ser bien en salas de conferencias, bien por la radio, para ser también retrasmitidas a las Islas Canarias. Las conferencias se celebrarían los primeros 15 días en Madrid y los 15 días siguientes en las ciudades de Barcelona, Bilbao, Sevilla, Valencia, Valladolid, Vigo y Zaragoza.

Los siete temas debían ser la base para una colección de 7 monografías de 500 páginas cada una, cuyos contenidos se encargarían a una serie de autores. En el volumen de Historia de Canarias, que debía coordinar Martínez Santa-Olalla (ASO s/f), cabe resaltar Canarias y la Atlántida por Pérez de Barradas, Prehistoria española y Prehistoria africana-Canarias por Martínez Santa-Olalla, La religión indígena por Pérez de Barradas, Pinturas, grabados, signos por Martínez Santa-Olalla, Megalitos por Martínez Santa-Olalla, El descubrimiento y la conquista por Carmelo Viñas Mey, Canarias y la conquista de Indias por Antonio Ballesteros, Canarias en el siglo XVIII y XIX por Pío Zabala, Arte Popular por Pérez de Barradas, Vida Rural por Pérez de Barradas o la Exploración científica de Canarias por Pérez de Barradas. Quizás lo que llama más la atención es la ausencia de investigadores consolidados de las Islas Canarias, como Serra Ràfols o el propio Darias y Padrón.

Evidentemente, uno de los problemas eran los costes de la exposición en una situación económica muy difícil, donde el grueso de la inversión se destinaba al ejército. Las actividades implicaban el viaje de los conferenciantes, de los actores teatrales, de los participantes en los actos musicales que incluían orquesta de cámara, rondallas, grupos de baile, coros y comparsas, grupo de lucha canaria, etc.

Pronto empezaron a hacerse cambios y a acumularse retrasos por insuficiencias presupuestarias. En una reunión el 22 de abril, a la que asistieron Martínez Santa-Olalla y Pérez de Barradas (FD2005/1/21, 52 ), ya les informaron de su retraso hasta «julio o septiembre».

Martínez Santa-Olalla trató también de publicar un monográfico en un fascículo de las Actas y Memorias de la Sociedad Española de Antropología, Etnología y Prehistoria, y poder darle proyección internacional a la prehistoria y antropología de Canarias gracias a los intercambios de la revista, pero para ello precisaba dinero que le solicitó a Cabanas (ASO, 5-5-1941).

Cuando debería estar concluyéndose la exposición el 15 de junio, si se hubieran cumplido los plazos previstos, dos días después publicaba el diario Arriba un artículo, Como estará organizada la Sala de Historia de la Exposición de las Islas Canarias, que se apoyaba en información cedida por Martínez SantaOlalla, donde agradece especialmente la colaboración de Jiménez Sánchez y Darias y Padrón. En el artículo se menciona el segundo de los problemas que afectaba la exposición, el retraso en la inauguración del Palacio de Exposiciones Regionales en la Plaza de España «que será inaugurado en breve».

En este artículo se informa que la monografía de la sección de Historia que coordinaba Martínez Santa-Olalla, había sido reestructurada, reduciéndose el número de colaboradores a 5 capítulos, Prehistoria Canaria por Martínez Santa-Olalla, Conquista de Canarias por Viñas Mey, Las Islas Canarias en la politica americana y africana de España por Darias y Padrón, Canarias, baluarte de la Hispanidad por Darío Fernández Flores, novelista y autor teatral, de la Vicesecretaría de Educación Popular de Falange, que por entonces alcanzó «prestigio» por su ensayo Dos claves históricas: Mio Cid y Roldán en 1939, y finalmente, La historia social y económica de Canarias por Alonso del Real y Ramos. Como puede observarse, Martínez Santa-Olalla había optado por ceñir el grupo de colaboradores a personas muy próximas a él, el catedrático falangista de la facultad, Viñas Mey, el Secretario de la Comisaría General de Excavaciones Arqueológicas, Alonso del Real, e incorporaba al Comisario Provincial de las Canarias Occidentales, Darias y Padrón. La decisión la había tomado a inicios de mayo, según le comunicaba a este último (ASO, 7-5-1941). El texto de Darias y Padrón seguía sin entregarlo en octubre, volviéndoselo a reclamar Martínez Santa-Olalla (DDP 36/22/2.66, 12-10-1941).

El primer acto oficial del programa fue la apertura de la Exposición de Carteles murales anunciadores de la Exposición de las Islas Canarias, que se inauguró el 25 de junio en el Ateneo de Madrid, por entonces, sede de la Delegación Provincial de Educación Nacional, a la que Cabanas invitó a Martínez Santa-Olalla (ASO, 19-6-1941), pero Pérez de Barradas estaba desmotivado y decidió no asistir (FD2005/1/22, 38).

El retraso en la construcción del pabellón de la exposición y la falta de dinero lastró el proyecto. Se siguieron acumulando retrasos, y carecemos de menciones hasta que J. Losada de la Torre menciona en su artículo, España en España, en $A B C$ de 19 de octubre de 1941, que la exposición estará abierta durante un mes en la Plaza de España como «homenaje a la clara españolidad de las islas», pero aún sin precisar fechas, «se realizará en plazo brevísimo». Pocos días antes, el 8 de octubre, el periodista de $A B C$, spectator, resaltaba que aún estaba con la «estructura casi terminada» el pabellón de exposiciones en la Plaza de España, diseñado por Aróztegui para la futura Exposición de las Islas Canarias que dirigía Cabanas.

El 4 de noviembre de 1941 se inauguró en el Círculo de Bellas Artes de Madrid una exposición de fotografías de las Islas Canarias, con una selección de las 5.000 tomas que había realizado el fotógrafo Augusto Valmitjana, presidida por el arquitecto Francisco 
Íñiguez Almech, Director General accidental de Bellas Artes.

Un año después Martínez Santa-Olalla le señalaba a Darias y Padrón que la exposición «ha sufrido un parón extraordinario e incluso dudo que se haga nada, no obstante me parecería muy bien que de manera muy clara y terminante escribiera Vd. a Cabanas sobre esto» (DDP 36/22/2.71, 28-3-1942).

\section{LA GÉNESIS DE LA COMISARÍA PROVINCIAL DE EXCAVACIONES EN LAS PALMAS DE GRAN CANARIA: JOSÉ JIMÉNEZ SÁNCHEZ}

El organigrama básico de la Comisaría General de Excavaciones Arqueológicas se estableció en Madrid el 1 de mayo de 1939, formado por un secretario, Carlos Alonso del Real y Ramos, dos ayudantes personales, Clarisa Millán García y María Luisa Herrera Escudero, una mecanógrafa María Luisa Montalvo de Ángel, un fotógrafo y un ordenanza. A los 13 meses, aún todos seguían sin cobrar (Gracia, 2009, 230-231, 233). En 1939 se solicitó en julio y diciembre 83.119 pesetas para excavaciones arqueológicas, pero no se concedió dinero (Gracia, 2009, 265-266). Para 1940, la solicitud fue de 194.625 pesetas, de la que tampoco se recibió nada (Gracia, 2009, 267 tabla). En 1941, el nuevo presupuesto solicitado en abril era de 232.000 pesetas, pero fue rebajado a 142.721 pesetas y finalmente tampoco fue librado por no haber tiempo real de gasto en diciembre de 1941 (Gracia, 2009, 267, 270, 268 tabla). Es importante indicar que el propio Martínez SantaOlalla reconocía que la partida inicial de 1941 sólo era «la cuarta parte de lo que se gastaba antes de la guerra» (DDP 36/22/2.71, 28-3-41).

Sin embargo, la documentación de las Islas Canarias muestra en detalle como el organigrama comenzó a funcionar desde 1939 a escala provincial, aunque se carecía de financiación. Aprovechando la estancia de José Pérez de Barradas en Las Palmas, cuando regresaba de Colombia entre septiembre de 1938 y enero de 1939, se creó un lazo importante con Sebastián Jiménez Sánchez, Secretario de El Museo Canario. Esta institución contrató a Pérez de Barradas para ayudarle económicamente, durante 3 meses, entre octubre y diciembre de 1938, para realizar el Catálogo de la colección de cerámica, y objetos arqueológicos (Salas Grau y Navarro) (Pérez de Barradas, 1944) y redactar una síntesis de la prehistoria canaria que publicaría el museo, Estado actual de las investigaciones prehistóricas sobre Canarias (Pérez de Barradas, 1939; Farrujia y del Arco, 2002; Navarro, 2008).

La toma de Madrid por los nacionales no fue hasta el 28 de marzo y aún con el primer Gobierno de Burgos, que había sido nombrado el 31 de enero de 1938 , en poco más de un mes comenzó a funcionar la Comisaría General de Excavaciones Arqueológicas, dentro de Educación Nacional, que dirigía Pedro Sainz Rodríguez.
Sebastián Jiménez Sánchez, periodista, maestro, funcionario en la Junta Administrativa de Obras Públicas de Las Palmas desde 1934, Delegado Provincial de Educación Popular y Jefe de Censura y Publicaciones de Falange Española Tradicionalista y de las J.O.N.S. estaba bien informado por Pérez de Barradas y apenas 10 días después de constituirse la Comisaría General, Jiménez Sánchez le contestaba a Pérez de Barradas (FD2005, 11-5-1939) que ya había trasmitido sobre «la autorización para excavaciones y exploraciones arqueológicas, del Ministerio», de lo cual «dí cuenta de ello a la Junta de Gobierno [de El Museo Canario], estimándose como es natural», pidiéndole su colaboración para que les informase «de las disposiciones referentes al particular»y «nos redacte un borrador de instancia».

Al no enviárselo, volvía a insistir Jiménez Sánchez al mes siguiente, recordándole «lo referente a excavaciones» (FD2005, 15-7-1939), y de nuevo en agosto, «Respecto a lo que me dijo sobre exploraciones ruégole nos manifieste detalladamente los pasos que hay que dar para proseguir dichos trabajos. Le agradeceré un modelo de instancia» (FD2005, 9-8-1939).

El descubrimiento de unas vasijas completas en la finca El Roque (Telde), a mediados de julio de 1939, acabó propiciando una relación directa con Martínez Santa-Olalla. Según le relataba Jiménez Sánchez a Pérez de Barradas, «Hace mes y medio aparecieron fortuitamente en una finca de la vecina ciudad de Telde, al hacerse por su dueño unas obras de 'sorriba', cuatro vasos de cerámica guanche y un molino. El hallazgo fue publicado en la prensa local y telegrafiado a la prensa de ahí [Madrid], cosa que motivó a que el Comisario General de Excavaciones Arqueológicas dirigiera al Gobernador Civil de esta Provincia un telegrama solicitando informes sobre el asunto y el envío a Madrid de los vasos hallados. El Gobernador pidió informes a El Museo Canario, exponiéndole éste que sólo sabía lo que la prensa había dicho. El Sr. Gobernador Civil se incautó de los citados vasos y sé que se dirigió en oficio informe al Comisario Nacional de Excavaciones Arqueológicas en el que además de hacer historia del hallazgo solicita de la Superioridad que los expresados vasos y demás objetos sean entregados para su custodia en El Museo Canario (...) pues contribuiría a completar nuestra magnífica colección de cerámica», indicándole que «Usted nos puede ayudar en esto muchísimo, por su conocimiento del asunto, el cargo que ocupa ahí y por ser Socio Correspondiente de El Museo Canario», «con el atento ruego que siga la pista a aquélla y obtenga un informe favorable» (FD2005, 29-8-1939).

Aprovechaba para insistir Jiménez Sánchez en que «Es indispensable que se conceda a 'El Museo Canario', como tal Corporación científica, especial representación o delegación de la Jefatura Nacional de Excavaciones Arqueológicas, para hacer exploraciones y excavaciones en todo el Archipiélago, y en particular en la Provincia de Las Palmas, y que los objetos que se hallen sean depositados en nuestro Museo», advirtiendo que «Caso de haber dificultad para otorgar 
esa representación a la Entidad y ser necesario concederlo a una persona, puede disponer de mi nombre» (FD2005, 29-8-1939).

También presionó el Director de El Museo Canario, Rafael Cabrera Suárez, por carta del 18 de agosto al Gobernador Civil, para que las cerámicas fuesen depositadas en dicho museo como hasta entonces se había venido realizando. En este sentido le comentaba Jiménez Sánchez en una carta al futuro Comisario Local de Telde, Pedro Hernández Benítez, sobre las cerámicas, «Tres de ellos son semejantes a otros que poseemos, otros no. En verdad es una pena que salgan de aquí» (Ramírez, 2004, 130).

La ausencia de noticias ya se lo recriminaba Jiménez Sánchez a Pérez de Barradas pasado un mes, «Hace algún tiempo escribí a Vd. (...) En mi carta le rogaba que, con el mayor interés y cariño se preocupara por lo que en ella se exponía (...) Por aquí, amigo Pérez de Barradas, hay cierta atmósfera contra $\mathrm{Vd}$., por estimar que a $\mathrm{Vd}$. se debe la resolución recaída en lo que en la instancia que le enviamos se expresa; y más lo creen al preguntar si ha habido contestación de Vd. y decirle que no, como en verdad es» (FD2005, 4-11-1939).

Apenas 10 días después, le insistía en la necesidad de nombrar personas responsables del patrimonio arqueológico en las islas, «en materia de protección arqueológica nacional me parece que existen zonas o regiones al frente de las cuales figura una persona designada por el Comisario General. Creo que Canarias pertenece a la zona meridional con residencia en Sevilla. Ello me parece un grave error, en cuanto a Canarias, por su lejanía, estructura especial e historia debe constituir una zona o región. ¿Por qué no gestiona se cree en Las Palmas esa Jefatura para ver, inspeccionar y resolver los asuntos que en materia arqueológica como en la histórica se presente» (FD2005, 16-11-1939).

No obstante, Pérez de Barradas ya había hablado con Martínez Santa-Olalla, «Hablé con el Comisario General del problema de Canarias repetidas veces y precisamente por su resistencia en enviar lo de Telde es por lo que está todo paralizado». Había decidido que se trasladasen a Madrid las cerámicas pues debían «contribuir a que aquí [en Madrid] se despierte interés por la arqueología canaria, de la cual no hay nada en los museos por lo cual es desconocida». En compensación, ya en su carta del 28 de noviembre, le anunciaba que «Una vez que se reciba lo de Telde se le nombrará Comisario de zona, pero para hacer una labor nacional» (Ramírez, 2004, 130-131). Esto es, que priorizase los intereses de la Comisaría General frente a los de El Museo Canario.

Esta promesa se materializó cuando se le nombró Comisario Insular de Excavaciones Arqueológicas en Gran Canaria, el 15 de enero de 1940, cuyas competencias se ampliaron como Comisario Provincial de Excavaciones Arqueológicas el 29 de mayo (Ramírez, 2000, 422; 2002, 550).

Una de las primeras gestiones de Jiménez Sánchez fue conseguir la cesión a titularidad pública del Estado de algunos de los principales yacimientos de la isla como el Cenobio del Valerón (Santa María de Guía), Los Mugaretes del Clavo (Gáldar) o la Cueva Pintada de Gáldar (DDP 36/22/2.4, 2-6-1940).

$\mathrm{Su}$ primera excavación la realizó en los dos túmulos junto al Roque Antigafo o Partido, en el puerto de Las Nieves de Agaete, en agosto de 1940, hallados por soldados, cuando se realizaban obras de fortificación durante la Segunda Guerra Mundial, siendo informado por el Alcalde y el Comandante Militar de Agaete. Los dos túmulos, con cista orientada al Oeste, estaban enterrados a $1.20 \mathrm{~m}$ de profundidad, separados entre sí por $4 \mathrm{~m}$, y tenían unos $1.85 \mathrm{~m}$ de diámetro y $0.40 \mathrm{~m}$ de altura, recubriendo una cista de $0.70 \times 0.30 \mathrm{~m}$, localizando en cada una los restos de un hombre adulto ( $\mathrm{Ji}$ ménez Sánchez, 1936-40, 169-170 y 1941, 135-136). Posteriormente, en septiembre de 1940, documentó la presencia de casas y túmulos en el poblado de Los Caserones (La Aldea de San Nicolás de Tolentino) (Jiménez Sánchez, 1952a; 1952b).

La organización de la Exposición de Canarias propició el retorno de Pérez de Barradas a las islas y el primer contacto personal de Jiménez Sánchez con Martínez Santa-Olalla. Durante la estancia entre el 8 y 14 de marzo de 1941, se seleccionó que debería figurar en la exposición. En el aspecto de la fotografía, se advirtió que el fotógrafo Valmitjana no contaba con el equipo fotográfico adecuado para fotos en detalle. Se planteó la necesidad de reproducciones, pues no se autorizó a trasladar a Madrid ni el Pendón de la Conquista, regalo de Isabel la Católica en 1478 al Obispo y conquistador de Canarias, Juan de Frías, que ya había figurado en el desfile de la victoria (FD2005, 11-5-1939), ni tampoco las banderas de las milicias canarias del Tesoro de la Catedral. Se decidió la realización de 6 maquetas, tres de conjuntos artísticos, una con la Catedral de Las Palmas de Gran Canaria, otra con la Iglesia del Pino de Teror y una tercera de la Capilla de San Telmo y San Bernardo de Las Palmas de Gran Canaria, y tres arqueológicas, una de casas cruciformes de Gáldar, el túmulo de La Guancha de Gáldar y una casa honda de Fuerteventura. Dos dioramas de yacimientos prehistóricos, uno de la Cueva Pintada de Gáldar y otro de Cuatro Puertas en Telde. Préstamo de documentación histórica de El Museo Canario y de la colección del VII Marqués de Acialcázar, Pedro María Pinto y de Quintana. Entre las gratificaciones que recibía Jiménez Sánchez estaba impartir en Madrid una conferencia, junto con otras de Eduardo Benítez Inglott, director entre 1940-52 del actual periódico de La Provincia e historiador, y Luis Doreste Silva, poeta y periodista que había sido secretario personal del Embajador de España en París, Fernando León y Castillo, entre 1916-31. Por otra parte, permanecería en Madrid «con la antelación precisa para la instalación de la Sala». El presupuesto se fijaba en 12.000 pesetas (ASO, 14-3-1941).

Apenas una semana después, Jiménez Sánchez presentaba un presupuesto desglosado que nos precisa algunos elementos más de lo que pensaba exponer. En 
la arqueología, estaba previsto exponer 4 cráneos «de cada uno de los tipos Cromagnon, semita y negrítico». Reproducir fotografías de buena parte de las ilustraciones, algunas con aborígenes, del libro de Leonardo Torriani (1592), Descrittione et historia del Regno del Isole Canarie già dette Fortunate, que acababa de publicar Wölfel (1940a) en Leipzig y trasladar el manuscrito de las Ordenanzas de Gran Canaria. De un dibujo de Torriani quería prepararse un diorama con un efequen o santuario de Fuerteventura. Elaborar un mapa con las principales batallas entre canarios y castellanos durante la conquista. Sugería también Jiménez Sánchez fotografiar a las momias de Tenerife existentes en el Museo Etnológico Nacional.

Se incrementaban en dos el número de maquetas históricas, sumando la casa y calle donde vivió Colón y otra del Castillo de la Luz en Las Palmas. Las maquetas realmente suponían el grueso de la inversión, 5.700 pesetas, con algunas de gran coste como la Catedral de Las Palmas, con $1.50 \mathrm{~m}$ de altura, que ella sola suponía 3.000 pesetas, y también destacaba el coste de la reproducción del pendón de la conquista y banderas con 2.000 pesetas, o de 3 mapas históricos con 3.000 pesetas, sumando en conjunto 12.800 pesetas (ASO, 23-3-1941). Para ahorrar desplazamientos, se advertía que Jiménez Sánchez, Benítez Inglott y Doreste darían las conferencias no sólo para la Sala de Historia sino también para la de Folklore, que coordinaba Pérez de Barradas.

La realidad financiera pronto empezaría a dar problemas, y sólo una semana después, a fin de marzo, Jiménez Sánchez indicaba que «la Comisión no me ha dejado ni un céntimo, creándome con ello un gravísimo trastorno. Los obreros han tenido que parar sus trabajos de maquetas por carecer de material (...) Cabanas quedó en entregarme algo y a pesar de mis insistencias, aun en la misma noche de partida», advirtiendo que lo dejaban «en situación tan difícil y desairada y en verdad poco edificante (...) pues todos recurren a mi modesta persona por ser el Secretario director de orquesta» (ASO, 31-3-1941). En todo caso, Jiménez Sánchez, con su habitual eficiencia, ya escribía con membrete oficial de la «Exposición de las Islas Canarias. Comité Ejecutivo. Las Palmas de Gran Canaria» y disponía de una secretaría con personal en un local facilitado por el Cabildo Insular, pero evidentemente, Ridruejo no había explicado las razones últimas de la exposición, que interpretaba Jiménez Sánchez como un «hermoso acto de reparación a las Islas olvidadas» (ASO, 31-3-1941).

Como adelanto para las salas de Historia y Folklore se le acabaron girando 6.000 pesetas, que se dio en entregas a cuenta para las maquetas, acuarelas, vaciados, etc. No obstante, tuvo que entregar también 200 pesetas para el fotógrafo Valmitjana, que seguía sacando fotografías, pues estaba «muy apurado de fondos para regresar (...) una vez quedó aquí solo», y en particular, 745 pesetas de taxis en Lanzarote gastados por los que elaboraban los documentales, que le obligó a pagar el Delegado del Gobierno en Lanzarote (ASO, 28-4-41; FD2005, 28-4-41).
En todo caso, a fines de abril, ya estaban preparados la mayor parte de los elementos expositivos, pues su inauguración estaba prevista para el 15 de mayo de 1941, y su desglose nos revela algunos nuevos aspectos de lo que se pensaba exponer en la parte de arqueología de la exposición: 30 vaciados de pintaderas canarias, ídolos y vasos de cerámica; 6 dibujos de tipos canarios aborígenes, seguramente siguiendo a Torriani; 25 fotografías del manuscrito original de Torriani de 1592; 15 acuarelas de cerámica pintada de Gran Canaria e ídolos; acuarelas de la Cueva Pintada (Gáldar), Cuevas de la Montaña de Cuatro Puertas (Telde) y Tagoror-Sabor de la Montaña del Gallego (Santa María de Guía); fragmentos originales de cerámica aborigen y de tejidos de junco y palma; fotografías de José de Viera y Clavijo, Sabino Berthelot, Gregorio de Chil y Naranjo, René Verneau, y de conquistadores como Juan de Béthencourt y Pedro de Vera; denuncia del poeta Cairasco de Figueroa a la Inquisición; o los tomos 1 y 3 de la obra de Chil y Naranjo (1876 y 1891), Estudios históricos, climatológicos y patológicos de las Islas Canarias (ASO, 28-4-41), materiales que no fueron remitidos hasta el 29 de julio (ASO, 287-41). También conocemos la remisión por Darias y Padrón de fotos de láminas antiguas de la Cueva de Chinguaro (Güímar, Tenerife) y de una cueva guanche de Tenerife (DDP 36/22/3.41a, 2-8-1941), que suponemos tomadas de Berthelot (1839/1981).

En cambio, El Museo Canario no era partidario del envío de manuscritos originales y libros «raros», comunicando dos semanas después a Martínez SantaOlalla que «hay aquí marcada oposición», indicándose que se pidieran de los existentes en el Archivo de Simancas de Valladolid, o en particular, en la Biblioteca Nacional de Madrid, cuyo bibliotecario era el grancanario de Guía, Miguel Santiago Rodríguez, el cual si bien se había reincorporado a su puesto después de la Guerra Civil en mayo de 1939, Jiménez Sánchez desconocía que dos meses antes, en febrero de 1941, acaba de ser trasladado al Archivo General y Biblioteca del Ministerio de Asuntos Exteriores.

También resulta interesante que el cura de Telde, Pedro Hernández Benítez, futuro Comisario Local de Excavaciones Arqueológicas, «nos facilite con carácter devolutivo varias piezas de su pequeño Museo, que llevaré yo personalmente».

Una de los elementos más caros, la reproducción del Pendón de la Conquista, que costaba casi 2.000 pesetas, se descolgaba por la falta de fondos, señalando sutilmente como excusa que «No he encontrado telas apropiadas para reproducir el Pendón» (ASO, 12-5-41).

Al carecer de un macro adecuado, el fotógrafo Valmitjana no había podido hacer fotos de suficiente detalle de las piezas arqueológicas de El Museo Canario o de piezas de orfebrería de la Virgen del Pino en Teror. Este problema trató de solucionarlo Martínez Santa-Olalla solicitando las fotos que tuviesen disponibles en El Museo Canario, a través del director de la exposición, Cabanas, y enviando al fotógrafo a documentar las piezas 
de Canarias, en particular, las momias, existentes en el Museo Etnológico Nacional (ASO, 21, 24 y 30-7-41).

El proyecto de Martínez Santa-Olalla de publicar también un monográfico en un fascículo de 400 páginas y 60 o 70 láminas de las Actas y Memorias de la Sociedad Española de Antropología, Etnología y Prehistoria, y darle proyección internacional a la prehistoria y antropología de Canarias (ASO, 5-5-1941), le fue comunicado a Jiménez Sánchez casi 3 meses más tarde, como miembro de la sección canaria de la SEAEP, indicándole que buscase colaboradores para el monográfico (ASO, 30-7-41). Este le anunció 15 después una colaboración propia titulada «Viviendas primitivas de guanches y canarios» (ASO, 14-8-41), remitida finalmente en septiembre como Viviendas aborígenes de guanches y canarios, junto con otra de Hernández Benítez, Las inscripciones y grabados rupestres de Canarias y una tercera de Bosch Millares, Estigmas sifiliticos en los guanches (ASO, 18-9-41).

Con la publicación del libro de Wölfel (1940a) sobre Torriani se reinició en la isla el interés por los grabados rupestres. Durante la Segunda República, Wölfel había visitado yacimientos arqueológicos de Gran Canaria entre el 21 de enero y el 14 de febrero de 1933, que posteriormente recogió en un apéndice del libro, incluyendo el Barranco de los Letreros de Balos (Agüimes), Cuatro Puertas-Montaña Bermeja (Telde) y el Roque Bentayga (Tejeda), identificando a los de Balos como escritura alfabética del paleo-numídico (Wölfel, 1940b, 305-310; 1942, 107, 151-155).

La prospección de este sitio fue continuada por Hernández Benítez en 1941, identificando figuras antropomorfas «auténticamente guanches, inscripciones númidas, inscripciones latino-romanas, inscripciones y grabados rupestres simbólicos latino-cristianos y grabados cristianos de la Edad Media») (Hernández Benítez, 1945, 4-14, fig. 1-14; 1958, 20), colaborando inicialmente Jiménez Sánchez (1942, 34-35) con Hernández Benítez en el calco de los grabados. Poco después, realizó prospecciones y calcos en solitario que «vienen a completar, en parte, a los recogidos y descubiertos por nuestro común amigo el Pbro. Hernández Benítez» (ASO, 30-7-41), remitiéndole copia de sus calcos a Madrid a través de un periodista del diario Arriba (ASO, 14-8-41).

Ese año de 1941, la Comisaría General de Excavaciones había previsto financiar con 6.000 pesetas las excavaciones de Jiménez Sánchez en Gáldar, que se mantuvieron cuando se obligó a reducir las excavaciones previstas el 4 de diciembre y se presentó un nuevo desglose el 13 de diciembre, rechazado finalmente por el Ministerio al no haber tiempo suficiente para gastarlo (Gracia, 2009, 268 tabla, 270). Después de las presumibles gestiones de Martínez Santa-Olalla durante su viaje en marzo de 1941, y del propio Jiménez Sánchez, se contaba también con el compromiso del Cabildo de Gran Canaria de otras 10.000 pesetas cuando este dinero se librase, «Desde luego está acordado» (ASO, 30-7-41). El objetivo de Jiménez Sánchez era continuar la excavación realizada por miembros de El Museo Canario entre enero y abril de 1934 en los túmulos de La Guancha y El Agujero y de un conjunto de casas anexo (Pérez de Barradas, 1939, 29-30; Jiménez Sánchez, 1941, 138, 140).

\section{EL ORIGEN DE LA COMISARÍA PROVINCIAL DE EXCAVACIONES EN SANTA CRUZ DE TE- NERIFE: DACIO DARIAS Y PADRÓN}

En la provincia de Santa Cruz de Tenerife fue nombrado Dacio Darias y Padrón. Nacido en Valverde, capital de la isla de El Hierro, el 22 de marzo de 1880, fue designado en 1918, con 38 años, Cronista Oficial de la Isla de El Hierro y su obra principal era Noticias Generales Históricas sobre la Isla del Hierro, con un breve capítulo sobre el «periodo prehistórico» (Darias y Padrón, 1929/1980, 19-29). Hijo de un militar, se retiró como Capitán de Infantería en 1907, con 27 años, e inició estudios de Maestro de Primera Enseñanza, impartiendo después clases en La Gomera, El Hierro y finalmente en Tenerife. Periodista, director de la Gaceta de Tenerife hasta 1919, fue propietario-cofundador de la Revista de Historia entre 1924-27, junto con José Peraza de Ayala. El 29 de octubre de 1936 fue nombrado Comandante Militar de la isla de El Hierro, que desempeñó hasta el 27 de febrero de 1937, y dos años después, Comandante Militar de la isla de La Palma entre el 21 de marzo de 1939 hasta el 26 de julio (Ayala, 1999, 20-22), ocupando también en Falange el cargo de Jefe Provincial de Artesanía, al menos en 1940 y 1941 (DDP 36/22/3.37, 11-4-1941).

Acabada la Guerra Civil recibió una visita del también periodista Jiménez Sánchez en La Laguna, a finales de octubre de 1939, quien poco después le agradecía sus atenciones por carta al regresar el 3 de noviembre (DDP 36/22/2.2). Nombrado Jiménez Sánchez como Comisario Insular de Excavaciones Arqueológicas en Gran Canaria, desde el 15 de enero de 1940, debió recomendar a Martínez Santa-Olalla el nombramiento para Tenerife de Darias y Padrón, con quien tenía buena relación personal. Esto lo confirma Jiménez Sánchez, el 16 de mayo de 1940, cuando le señala a Darias y Padrón que «no tiene porqué agradecerme nada, hice la propuesta porque creí que nadie mejor que V., ni con más derecho y competencia» (DDP 36/22/2.3). En todo caso, ya antes de su nombramiento, el propio Martínez Santa-Olalla había escrito en abril al Director del Museo Municipal de Santa Cruz de Tenerife, Miguel Tarquis, para que le informase de hallazgos arqueológicos que se habían producido en la isla durante la Dictadura de Primo de Rivera y la Segunda República (AGA 296, 17-4-1940).

Las razones de la elección de Darias Padrón las resume Martínez Santa-Olalla en el momento de su renuncia, «sus trabajos tan decisivos para aclarar los primeros tiempos de la conquista de Castilla, sus monografías históricas, la fundación por él de la Revista 
Histórica de La Laguna que durante muchos años dirige y de manera especial su Historia de las Islas $\mathrm{Ca}$ narias que es el mejor resumen de Historia Canaria») (AGA 296, 16-11-1942).

Pocos días después informó de su nombramiento como Comisario Insular de Excavaciones Arqueológicas al Capitán General de las Islas Canarias (DDP 36/22/2.4, 22-5-1940). La situación preeminente de Jiménez Sánchez para el ámbito canario se refleja cuando Darias y Padrón le sugirió la persona de Manuel Sánchez y Rodríguez, Presidente de la Sociedad Cosmológica de Santa Cruz de La Palma, creada en 1881, para su nombramiento como Comisario Insular de Excavaciones Arqueológicas en La Palma, sobre la cual Jiménez Sánchez indica que «me parece bien» (DDP 36/22/2.7, 2-6-1940), de lo cual informó a Martínez Santa-Olalla (DDP 36/22/2.11, 19-6-1940).

No obstante, teniendo Darias y Padrón inmediato conocimiento que las competencias arqueológicas se habían ampliado para Jiménez Sánchez de Comisario Insular a Comisario Provincial de Las Palmas de Gran Canaria el 29 de mayo, Darias y Padrón escribió a Martínez Santa-Olalla, quien le señalaba el 3 de junio que «no hay inconveniente alguno en que se haga $\mathrm{Vd}$. cargo de las islas menores» (DDP 36/22/2.8). Su objetivo principal era su isla natal de El Hierro, pero también informaba por carta del 27 de junio al Presidente del Cabildo Insular de La Palma para comunicarle que la Comisaría Insular se había transformado en Comisaría Provincial (DDP 36/22/2.13, 2-7-1940). Darias y Padrón designó como secretario de la Comisaría, para que le ayudase con la tramitación de la correspondencia, en particular cuando estaba ausente en el verano residiendo en El Hierro, a Arturo Salazar y Sánchez, profesor y secretario de la Escuela Normal de Magisterio (DDP 36/22/3.5, 22-6-1940).

Interesado siempre en que la Comisaría Provincial contase con un Museo Arqueológico donde depositar los hallazgos arqueológicos, Martínez Santa-Olalla encargó en julio a Darias y Padrón que visitase el Museo Villa Benitez, fundado en 1874 por Anselmo Benítez, para su posible compra (DDP 36/22/2.16, 8-7-1940), destacando de las colecciones la presencia de «dos momias guanches, unos treinta cráneos y algunos (...) molinos, morteros, leznas o agujas de hueso y pocos de alfarería» (DDP 36/22/3.11, 31-7-1940), pero el precio que le pidió su hijo, Adalberto Benítez, era de 125.000 pesetas (DDP 36/22/2.17, 25-7-1940), ya que no quería separar las colecciones de Ciencias Naturales de las arqueológicas, siendo desestimada su compra por Martínez Santa-Olalla (DDP 36/22/2.18, 9-8-1940).

En este periodo, la iniciativa de Darias y Padrón más significativa fue escribir el 22 de junio a todos los municipios de la provincia, una vez nombrado Comisario Provincial, para conocer si había yacimientos arqueológicos o edificios de carácter artístico en el municipio, cuestionario arqueológico que también publicó en la prensa para darle mayor difusión. Ante la falta de respuestas, «sin haber obtenido contestación alguna» (DDP 36/22/3.15, 22-8-1940), Martínez Santa-Olalla escribió al Gobernador Civil, quien ordenó el 17 de agosto hacer un cuestionario municipal para un Catálogo Artístico y Arqueológico de la Provincia, el cual rápidamente comenzó a ser respondido entre agosto y octubre de 1940.

Como puede observase en la figura 1 , no se respondió positivamente en la isla de La Gomera, aunque incluso le reiteró su solicitud Darias y Padrón quejándose al Delegado del Gobierno para que presionase al Presidente del Cabildo y a los alcaldes (DDP 36/22/3.22, 19-9-1940). De El Hierro contestaron los dos municipios, el Ayuntamiento de Valverde y el Ayuntamiento de Frontera (Álvarez Delgado, 1945, $415 ; 1948,197)$, y con diferencia son los más detallados, influyendo el origen herreño y peso social que tenía en la isla el propio Darias y Padrón. En cambio, en La Palma las respuestas son prácticamente negativas, aunque hay algunos datos de tipo histórico-artístico, lo que no deja de sorprender, ya que Darias y Padrón fue brevemente también Comandante Militar de la isla en 1939. Datos más detallados corresponden a Tenerife, en particular los ayuntamientos de Güímar, Puerto de la Cruz y Adeje, si bien casi todos los municipios indican algún yacimiento conocido.

En este sentido, el primer yacimiento que Darias y Padrón $(1952,179)$ informó a la Comisaría General fue El Julan (Frontera, El Hierro), el 2 de octubre de 1940 (DDP 36/22/3.24, 2-10-1940), solicitando dinero para realizar «exploraciones» arqueológicas en El Hierro, en particular sus «grabados rupestres libios llamados Letreros», que fue aceptado favorablemente por Martínez Santa-Olalla, aunque le advirtió que de momento no había dinero (DDP 36/22/2.50, 15-10-1940).

A fines de enero e inicios de febrero de 1941, Martínez Santa-Olalla realizó un viaje por Ifni, Tarfaya y Río de Oro en el Sahara. Coincidiendo con este viaje sabemos que realizó una escala en Santa Cruz de Tenerife muy a finales de enero de 1941, según le comenta en una carta a Diego Cuscoy (FLDC, 7-12-1950; Mederos y Escribano, 2011, 325). En este viaje debió encontrarse personalmente con Darias y Padrón.

Su segundo viaje coincidió con los preparativos de la Exposición de Canarias, si bien permaneció menos días que en Gran Canaria. Llegaron el día 10 de marzo, encontrándose con Darias y Padrón y regresaron el día 15, visitando las colecciones aborígenes en el Museo Municipal de Santa Cruz de Tenerife.

Ese mismo día se constituyó en la Sociedad Económica de Amigos del País de Tenerife, con sede en La Laguna, el Comité Ejecutivo para la Exposición de Canarias en Tenerife, que formaron junto a Darias y Padrón, nombrado Delegado Provincial; Elías Serra Ràfols, Catedrático de Historia de España de la Universidad de La Laguna; Buenaventura Bonnet y Reverón, Profesor Auxiliar de la Universidad y profesor de Instituto en Santa Cruz de Tenerife y el músico Rafael Hardisson y Pizarroso, interesado en el estudio de las endechas aborígenes (DDP 36/22/2.56, 15-3-41). 


\begin{tabular}{|c|c|c|c|}
\hline Ayuntamiento & Isla & Fecha de respuesta & Yacimientos \\
\hline Adeje & Tenerife & $\begin{array}{l}\text { DDP } 36 / 22 / 2.20,12-8-1940 \\
\text { DDP } 36 / 22 / 2.27,26-8-1940\end{array}$ & $\begin{array}{c}\text { No } \\
\text { Cueva Bco. Macayonce } \\
\text { Cueva del Conde } \\
\text { Cueva del Rey }\end{array}$ \\
\hline La Orotava & Tenerife & DDP 36/22/2.22, 20-8-1940 & Cueva del Tope del Guanche \\
\hline Güímar & Tenerife & DDP 36/22/2.22, 21-8-1940 & $\begin{array}{c}\text { Cueva del Cañizo, Bco. de Badajoz } \\
\text { Cueva del Polvo } \\
\text { Cueva de la Finca Belén } \\
\text { Cueva de Chinguaro } \\
\text { Malpaís de Güímar } \\
\text { Cueva de Chascais } \\
\text { Fuga del Roque, Bco. Amorín } \\
\text { Cueva de Cho Ceferino, Piedras Negras } \\
\text { Paso de María Rodríguez, Bco. de Herques }\end{array}$ \\
\hline Tegueste & Tenerife & AGA 296, 21-8-1940 & No \\
\hline Granadilla & Tenerife & DDP 36/22/2.25, 22-8-1940 & $\begin{array}{c}\text { Casa Blanca } \\
\text { Cueva del Bco. del Río }\end{array}$ \\
\hline Icod & Tenerife & DDP 36/22/2.26, 24-8-1940 & No \\
\hline Garachico & Tenerife & DDP 36/22/2.30, 27-8-1940 & Cueva del Conde \\
\hline Realejo Bajo & Tenerife & DDP 36/22/2.31,?-8-1940 & No \\
\hline Puerto de la Cruz & Tenerife & DDP 36/22/2.35, 13-9-1940 & $\begin{array}{c}\text { Cueva Plaza del General Franco } \\
\text { Cueva del Chami, Martiánez } \\
\text { Cueva de los Siete Palacios, Martiánez } \\
\text { Cueva del Caldero, Sancho } \\
\text { Cueva del Cuaco, Calle las Damas } \\
\text { Finca la Paz, Botánico }\end{array}$ \\
\hline Buenavista & Tenerife & DDP 36/22/2.37, 22-9-1940 & No \\
\hline Los Silos & Tenerife & DDP 36/22/2.39, 24-9-1940 & No \\
\hline La Victoria de Acentejo & Tenerife & DDP 36/22/2.43, 30-9-1940 & No \\
\hline Vilaflor & Tenerife & DDP 36/22/2.47, 4-10-1940 & Llevados a Puerto Cruz y La Orotava \\
\hline San Miguel & Tenerife & DDP 36/22/2.48, 10-10-1940 & Cueva de El Ochoa [Uchova] \\
\hline Hermigua & La Gomera & AGA 296, 21-8-1940 & No \\
\hline Vallehermoso & La Gomera & AGA 296, 21-8-1940 & No \\
\hline Valverde & El Hierro & DDP 36/22/2.32, 27-8-1940 & $\begin{array}{c}\text { La Candia } \\
\text { La Caleta } \\
\text { Tejeleita } \\
\text { Cueva Teseneita } \\
\text { Charcos del Árbol Santo } \\
\text { Cueva de la Pólvora }\end{array}$ \\
\hline Frontera & El Hierro & DDP 36/22/2.34, 7-9-1940 & $\begin{array}{c}\text { Letreros El Julan } \\
\text { Tagoro El Julan } \\
\text { Concheros El Julan } \\
\text { Cueva Bco. Garañones, El Julan } \\
\text { Los Santillos, Montaña Tambárgena } \\
\text { Cueva de Pedro Fernández } \\
\text { Cueva de Don Justo } \\
\text { Cueva del Hoyo } \\
\text { Conchero de las Lapas } \\
\text { Conchero de Guinea } \\
\text { Conchero de Merese } \\
\text { Espigón del Hoyo } \\
\text { Conchero Bco. del Bucian } \\
\text { El Calderetón, Sabinosa } \\
\text { Concheros de Las Eras }\end{array}$ \\
\hline Los Llanos & La Palma & DDP 36/22/2.22, 20-8-1940 & No \\
\hline Santa Cruz de la Palma & La Palma & DDP 36/22/2.33, 3-9-1940 & No \\
\hline Puntallana & La Palma & DDP 36/22/2.40, 27-9-1940 & No \\
\hline
\end{tabular}




\begin{tabular}{|c|c|c|c|}
\hline Tazacorte & La Palma & $\begin{array}{c}\text { DDP 36/22/2.41 y 2.54, 27-9- } \\
1940 \text { y 21-10-1940 }\end{array}$ & No \\
\hline Fuencaliente & La Palma & DDP 36/22/2.44, 2-10-1940 & No \\
\hline Puntagorda & La Palma & DDP 36/22/2.45, 2-10-1940 & Entregado a La Cosmológica, S/C Palma \\
\hline Barlovento & La Palma & DDP 36/22/2.46, 4-10-1940 & No \\
\hline Breña Alta & La Palma & DDP 36/22/2.51, 16-10-1940 & No \\
\hline Breña Baja & La Palma & DDP 36/22/2.52, 21-10-1940 & Cuevas sin datos \\
\hline Tijarafe & La Palma & DDP 36/22/2.53, 21-10-1940 & \\
\hline
\end{tabular}

Figura 1: Yacimientos citados en la encuesta para un Catálogo Artístico y Arqueológico de la Provincia de Santa Cruz de Tenerife, promovido en 1940 por Darias y Padrón y Martínez Santa-Olalla. Bco.=Barranco. Fondo Dacio Darias Padrón (DDP) y Archivo General de la Administración (AGA).

También Martínez Santa-Olalla seleccionó ese día, antes de partir, que debería figurar en la sala de Historia de la exposición. Entre las maquetas señaló la Iglesia de La Orotava y la de La Concepción de La Laguna. Entre los dioramas, uno grande con una cueva sepulcral aborigen con momias a partir de un grabado del siglo XVII, otro del Instituto de La Laguna, el Palacio del quinto marqués de Villanueva del Prado o Palacio de Nava de La Laguna, y de La Orotava, la ermita de Santa Catalina y casas solariegas. Reproducciones del Pendón de la conquista, de banderas de las milicias canarias y banderas capturadas a Nelson. Y dos vaciados, uno de los grabados de Los Letreros de El Julan (El Hierro) y otro del cañón Tigre que hirió a Nelson. Entre posibles publicaciones, una Guía histórica-artística de la provincia y la reedición ampliada del libro Breves nociones sobre la historia general de las Islas Canarias de Darias y Padrón (1934) (ASO, 15-3-1941), pero al pedir presupuesto surgió el problema que 500 ejemplares salían unas 5.500 pesetas (ASO, 18-4-1941).

El traslado de piezas arqueológicas del Museo Municipal quedó frustrado al negarse el director (FD2005/1/20), pero debieron haber presiones para que lo autorizase, pues Martínez Santa-Olalla le preguntó dos meses después «si las series arqueológicas del Museo Municipal de Santa Cruz de Tenerife, están seleccionadas» (ASO, 7-5-1941), aunque seguía sin tomarse una decisión definitiva (ASO, 16-5-1941). Como había sucedido con El Museo Canario, faltaban fotos de detalle de las piezas arqueológicas principales del Museo Municipal, pidiendo Martínez Santa-Olalla que se recurriese a un fotógrafo local para realizarlas (ASO, 28 y 30-7-41).

Sabemos que hubo un nuevo viaje en abril por parte de algunos miembros de la Exposición de Canarias, encabezados por Cabanas y acompañados por el Gobernador Civil, que por lo menos visitó La Palma, La Gomera y El Hierro. Este invitó a Darias y Padrón, quien acompañó en particular al fotógrafo Valmitjana, pero como le señalaba a Martínez Santa-Olalla, el viaje "se ha hecho muy a la ligera (...) perdiéndose bastante tiempo en agasajos». Se formó un comité en La Palma y al regresar a Tenerife quería seguir acompañando al fotógrafo en la isla, pues hasta entonces sólo había visitado La Orotava y el Puerto de la Cruz, pero por falta de dinero no había podido encargar nada para la exposición (ASO, 11-4-1941). Las fotos se realizaron durante varios días hasta que Valmitjana se marchó a Gran Canaria a continuar con las fotografías donde permaneció hasta avanzado el mes (ASO, 28-4-1941), pero Darias y Padrón seguía sin dinero para hacer los encargos. Se instaló en el Cabildo Insular una oficina para coordinar los preparativos de la exposición para la cual se nombró al pintor Francisco Aguilar y Paz (ASO, 18-4-1941), Delegado de Prensa y Propaganda de Falange y director del diario Amanecer.

El dinero comenzó a librarse a inicios de mayo (ASO, 7-5-1941), pero seguía sin cobrarlo el día 16, aunque Francisco Aguilar ya había recibido 25.000 pesetas para adelantos en las distintas salas (ASO, 164-1941), cuando en teoría la exposición debía haber comenzado el 15 de mayo. El presupuesto presentado por Darias y Padrón el 10 de mayo era mucho más elevado que el solicitado en Gran Canaria, alcanzando 31.550 pesetas, encarecido por las publicaciones, pues la guía de arte suponía 12.000 pesetas y la reedición de su historia, otras 6.000 pesetas. Eliminadas estas dos partidas, aún eran 13.550 pesetas, donde destacaban los gastos de las dos maquetas de las iglesias con 3.000 pesetas, los cuatro dioramas con 6.000 pesetas o las reproducciones de banderas con otras 2.000 pesetas. En cambio, descartaba el vaciado de los grabados de Los Letreros de El Julan, donde quería haber hecho su primera campaña arqueológica, «porque resultaría costoso hacer un viaje a la mencionada isla» (ASO, 10-5-1941). Aquí se advierte el diferente dinamismo entre Jiménez Sánchez y Darias y Padrón, pues el primero, que dispuso del dinero antes, al ser el responsable provincial, cargo que en Tenerife tuvo Francisco Aguilar, ya tenía preparados, a fines de abril, la mayor parte de los elementos expositivos.

Para las conferencias en Madrid se desplazarían también Juan Álvarez Delgado, Francisco Aguilar y quizás, en lo folklórico, Rafael Hardisson, aunque «no tiene preparado nada» (ASO, 16-5-1941). Por otra parte, Darias y Padrón permanecería en Madrid «con la antelación precisa para la instalación de la Sala» (ASO, 14-3-1941).

La preocupación por una posible entrada de España en la Segunda Guerra Mundial atenazaba en las islas y como señalaba Darias y Padrón (ASO, 16-5-1941), 
«El ambiente, por aquí, juzgando por apariencias, no parece muy entusiasta, por la Exposición; quizás por el cariz que va tomando la cuestión internacional, en la que acaso pudiéramos de la noche a la mañana, vernos envueltos»».

El proyecto de Martínez Santa-Olalla de publicar también un monográfico en las Actas y Memorias de la Sociedad Española de Antropología, Etnología y Prehistoria (ASO, 5-5-1941), le fue comunicado al Director del Instituto de Estudios Canarios de La Laguna 3 meses después, a comienzos del verano, para buscar colaboraciones entre sus miembros y también al propio Darias y Padrón (ASO, 30-7-1941). Estas participaciones fueron precisadas a inicios de septiembre por los dos miembros más relevantes del Instituto, el Presidente de la Sección de Historia, Elías Serra Ràfols, con Los indígenas en las Datas de Tenerife, que ya se lo había sugerido a Darias y Padrón meses antes (ASO, 18-4-1941), y el Presidente de la Sección de Literatura, Juan Álvarez Delgado, con Los aborígenes canarios a la luz de la Lingüística (ASO, 7-9-1941).

La Comisaría General de Excavaciones Arqueológicas consiguió su regulación con la Orden Ministerial del 21 de abril de 1941, publicada el 29, que se envió desde el Ministerio de Gobernación a todos los gobiernos civiles el día 26, y fue completada con otra Orden Ministerial del 30 de abril, publicado el 14 de mayo, que autorizaba a la Dirección General de Bellas Artes a efectuar el nombramiento de comisarios provinciales y locales (Díaz-Andreu y Ramírez, 2001, 328-329; Gracia, 2009, 242-244).

Darias y Padrón había insistido a Martínez Santa-Olalla en dar carácter oficial al nombramiento de Comisario Provincial y que se publicase en el B.O.E. pues el Cabildo de Tenerife no había contestado a su petición de solicitar un local para la Comisaría Provincial (ASO, 11-4-1941). Este se produjo inmediatamente, ya el 31 de abril, firmado por el Director General de Bellas Artes, comunicándoselo Martínez Santa-Olalla el 19 de mayo (DDP 36/22/2.61), tomando posesión en el Gobierno Civil el 30 de mayo (DDP 36/22/2.62).

Para las Canarias Occidentales, la Comisaría General de Excavaciones había previsto financiar en 1941 con 6.000 pesetas las primeras excavaciones de Darias y Padrón en cuevas de Tenerife, cifra que le anunció Martínez Santa-Olalla en marzo (DDP 36/22/2.71, 28-3-1941), volviéndole a indicar en septiembre que «muy en breve» lo recibiría (DDP 36/22/2.66, 22-91941), pero lo que sucedió es que se le obligó a reducir las excavaciones y cuantías previstas el 4 de diciembre y se presentó un nuevo desglose el 13 de diciembre donde seguía conservado la inversión para Tenerife, pero este segundo presupuesto también fue rechazado (Gracia, 2009, 268 tabla, 270). En todo caso, Darias y Padrón por lo que seguía mostrando interés era en trabajar en El Julan (El Hierro), como se lo volvió a señalar a inicios del verano de 1941, cuando estaba a la espera de la subvención, donde esperaba ir con un obrero que le ayudase (DDP 36/22/3.40, 5-7-1941).
Martínez Santa-Olalla contaba con un compromiso con el Presidente del Cabildo entre 1939-43, Francisco La-Roche Aguilar, de que si se invertía 10.000 pesetas por la Comisaría General, habría una financiación adicional por parte del Cabildo de Tenerife de otras 10.000 pesetas y un local para la Comisaría Provincial (DDP 36/22/2.66, 22-9-1941), pero ya Darias y Padrón en mayo avisaba que «La subvención del Cabildo a la Comisaría de Excavaciones no tiene ni probablemente tendrá, dado el estado agobiante de la hacienda insular, realidad», buscándose aún un local para la sede en el edificio del Cabildo (ASO, 16-5-1941). No obstante, poco después solicitó oficialmente la subvención de 10.000 pesetas anuales, cantidad que fue aceptada por la Comisión Gestora del Cabildo Insular de Tenerife el 10 de julio, pero se le comunicaba el 5 de agosto que, antes de aprobarla, «debe conocerse el programa de obras a realizar, así como también las realizadas» (DDP 36/22/2.63), lo que fue motivo de queja por Darias y Padrón a Martínez Santa-Olalla por exigirle resultados antes de disponer de financiación (DDP 36/22/3.45, 14-8-1941), pero acabó respondiendo en octubre que «se han limitado a levantar el censo arqueológico de esta provincia, con el concurso de alcaldías» (DDP 36/22/3.45, 11-10-1941). Al no recibirse el dinero de Madrid, tampoco el Cabildo libró su parte correspondiente.

En 1942 se aprobó el primer presupuesto de la Comisaría General, de 137.000 pesetas, presentado el 24 de marzo y aprobado finalmente el 27 de junio, antes del verano. Este presupuesto incluía 6.000 pesetas para excavación en cuevas de Tenerife a cargo de Darias y Padrón y 6.000 pesetas para excavaciones en El Agujero de Gáldar a nombre de Jiménez Sánchez, las cuales ya habían figurado en el presupuesto presentado en 1941 (Gracia, 2009, 276-277, 274 tabla). Para excavar durante el verano en Tenerife, Darias y Padrón se lo había propuesto a Serra Ràfols, pero éste no le había hecho ninguna propuesta en firme, mientras que él seguía pensando en investigar en El Hierro (DDP 36/22/3.54a, 22-4-1942). Ya le había advertido Martínez Santa-Olalla que «siendo la primera vez que el Estado consigna para estas atenciones en Canarias convendría hacer una campaña lucida aunque el poco dinero no pueda ser de gran volumen» (DDP 36/22/2.71, 28-3-1942). A inicios de junio, Darias y Padrón le escribió a Martínez SantaOlalla que se iba a El Hierro durante el verano, «en breves días», donde pensaba realizar algunos trabajos de campo, pues pidió ayuda al Gobernador Civil para que se lo comunicase al Delegado del Gobierno (DDP 36/22/3.56a-b, 5-6-1942). Darias y Padrón recibió la comunicación de la concesión de la subvención el 8 de julio (DDP 36/22/2.75), y una semana después le escribía preocupado Martínez Santa-Olalla indicándole que seguía sin recibir propuesta alguna de los lugares donde se iba a excavar (DDP 36/22/2.76, 15-7-1942).

$\mathrm{Su}$ respuesta fue a finales de julio, indicándole que pensaba prolongar su estancia en Frontera (El Hierro), «por motivos particulares, algunos meses» y no podría 
realizar las excavaciones en Tenerife. Como posibles alternativas para excavar en Tenerife sugería, en primer lugar, al canónigo de Tenerife, José García Ortega, que aparentemente ya había realizado excavaciones previas en Gran Canaria financiadas por el Cabildo. Era autor de un breve tratado sobre la aculturación de los guanches (García Ortega, 1935), Correspondiente en Tenerife de la Real Academia de la Historia desde el 3 de febrero de 1940 (Jiménez Díez y Mederos, 2001, 104 tabla 3) y miembro del Instituto de Estudios Canarios. En segundo lugar, al ingeniero jefe de montes de la provincia, Leoncio Oramas y Díaz; y finalmente a Serra Ràfols, pero estaba «actualmente ausente de La Laguna» (DDP 36/22/3.57, 30-7-1942), presumiblemente de vacaciones en Gerona. Probablemente, ya antes de recibir en Madrid esta carta escrita en El Hierro, Martínez Santa-Olalla le mandaba un nuevo aviso el 4 de agosto, cuando le señalaba que el dinero había que justificarlo a los 3 meses de recibirse la partida (DDP 36/22/2.79).

La posibilidad de disponer de financiación adicional por el Cabildo Insular de Tenerife forzaba a Darias y Padrón a excavar en Tenerife, pero donde realmente tenía interés de investigar era sobre los grabados rupestres de El Julan, en su isla natal de El Hierro. Por otra parte, su edad influía, había sido nombrado en 1940, cuando ya tenía 60 años. Además, carecía de cualquier experiencia previa en arqueología.

Desde la creación del Comité Ejecutivo para la Exposición de Canarias en Tenerife en marzo de 1941, se había establecido una relación estrecha con Elías Serra Ràfols, Decano de Filosofía y Letras y Catedrático de Historia de España de la Universidad de La Laguna, que además presidía la sección de la Sección de Historia en el Instituto de Estudios Canarios de La Laguna. Otro representante importante era Álvarez Delgado, Catedrático de Latín del Instituto Nacional de Bachillerato Femenino de La Laguna, Profesor interino de la Facultad de Filología Clásica de la Universidad de La Laguna, Subjefe Provincial del Movimiento y Delegado Provincial de Prensa y Propaganda de Falange Española Tradicionalista y de las J.O.N.S. Los tres colaboraban regularmente en la Revista de Historia de la Universidad de La Laguna, que había fundado Darias y Padrón. Así, en agosto de 1942, le agradecía Álvarez Delgado, en su nombre y en el de Serra Ràfols, director de la revista, las gestiones de Martínez SantaOlalla para conseguir el cupo de papel que permitiese seguir publicándose la revista (ASO, 1-8-1942).

El problema era buscar la persona adecuada para realizar los trabajos de campo. En abril de 1942, Darias y Padrón había autorizado a un maestro de El Tablado (Garafía, La Palma), Jesús Álvarez García, para realizar «excavaciones o exploraciones» a petición de Serra Ràfols (DDP 36/22/2.72, 17-4-1942). El intento de otra excavación de una cueva por un aficionado, el ingeniero jefe de montes de la provincia, Leoncio Oramas y Díaz, llevó al Gobernador Civil a pedir información, al que contestó Martínez Santa-Olalla que «no tiene autorizada ninguna excavación ni rebusca de ningún género salvo a los Sres. Serra Ràfols y Álvarez Delgado de la Universidad de La Laguna» (DDP 36/22/2.81, 17-9-1942).

La situación acabó irritando a Martínez Santa-Ola1la, bastante molesto porque no se hubiesen realizado aún excavaciones oficiales en Tenerife con la partida concedida, un tema sobre el que «son varios años los que llevamos hablando de ello» y para lo cual había otorgado un permiso con «un nombre vago», Cuevas de Tenerife, para ir decidiendo el lugar más adecuado. Le señaló que no admitía que se escogiesen aficionados como el maestro de Garafía, Álvarez García, el ingeniero de Tenerife, Oramas Díaz o el canónigo García Ortega que «es para mi un Sr. perfectamente desconocido que según creo nada ha hecho de arqueología», y «puestos a buscar sustitutos no habría más que el Sr. Serra Ràfols que Vd. indica o Álvarez Delgado que aunque no sean específicamente arqueólogos tienen una formación y una experiencia nada comunes»> (DDP 36/22/2.82, 17-9-1942). La elección se decantó finalmente por el más joven de los dos, aunque sólo 2 años menos, Álvarez Delgado, a quien además Darias y Padrón conocía desde muy joven, pues había sido su maestro en la escuela de Güímar. La decisión la tomó Martínez Santa-Olalla a finales de septiembre. Esto se observa porque ya el día 30 de octubre (AGA 296), Álvarez Delgado proponía hacer excavaciones no sólo en Tenerife, sino ampliarlas a la Fortaleza de Chipude, «donde hay huellas de construcción indígenas de tipo megalítico». Se podría pensar que esta carta inclinó la balanza, pero su misiva no llegó a Madrid hasta el 16 de noviembre, dos días después que lo propusiese como nuevo Comisario Provincial (AGA 296, 14-11-1942).

Dacio Darias y Padrón presentó su dimisión voluntaria al Director General de Bellas Artes como Comisario Provincial de Excavaciones Arqueológicas de Santa Cruz de Tenerife el 1 de noviembre de 1942 (AGA 296), recibida en Madrid el día 14, casi 15 días después, lo que era habitual para esos años durante la Segunda Guerra Mundial. La excusa era el seguir residiendo durante un tiempo indefinido en El Hierro. Ese mismo día 14 se lo comunicó Martínez Santa-Olalla por un oficio al Marqués de Lozoya, explicándolo dos días después, el 16 de noviembre, por haberse trasladado Darias y Padrón a la isla de El Hierro. En el indicaba que «Darias Padrón (...) ha desempeñado su cargo desde el momento que se creó la Comisaría con el mayor celo y diligencia y en condiciones tan desfavorables como son siempre las de creación y funcionamiento de un organismo nuevo». El día 14 también proponía como sustituto «para dicho cargo a Don Juan Álvarez Delgado, profesor de la Universidad de La Laguna y Catedrático de Instituto, personalidad bien conocida por sus relevantes trabajos de Historia Prehispánica en el Archipiélago Canario (...) De la actividad del Sr. Álvarez Delgado hay que esperar una gran intensificación en los trabajos arqueológicos en la provincia de Santa Cruz de Tenerife» (AGA 296, 14 y 16-11-1942; Ramírez, 2002, 563 n. 6-7). El nombramiento oficial por el 
Director General se consumó el 1 de diciembre, y fue trasladado a Martínez Santa-Olalla el día 3 (AGA 296) y por telegrama remitido después de tomar posesión en el Gobierno Civil de Santa Cruz de Tenerife, este no se produjo hasta el día 15 de diciembre (AGA 296). Muestra de su generosidad por los servicios prestados, Martínez Santa-Olalla propuso al Ministro el 16 de noviembre la concesión a Darias y Padrón de la Cruz de la Orden Civil de Alfonso X El Sabio, concedida el 23 de enero de 1943 (AGA 296).

Otro aspecto importante era no perder la partida concedida para excavaciones. Así, Martínez Santa-Olalla ya el 16 de noviembre solicitó el cambio del libramiento del dinero de Darias y Padrón a favor de Álvarez Delgado, lo que autorizó el Director General de Bellas Artes el 5 de diciembre (AGA 296), pues Darias y Padrón permanecía en El Hierro y sólo él podía cobrar el dinero en Tenerife (AGA 296, 15-12-1942). Además, trató de estimular a Álvarez Delgado ofreciéndole un incremento de la financiación, sumando a las 6.000 ya concedidas para Tenerife, otras 4.000 pesetas para excavar en La Fortaleza de Chipude en La Gomera, procedentes de la anulación de la excavación de Sanchorreja (Ávila) (Gracia, 2009, 276-277). Para valorar adecuadamente la importancia de este detalle y su interés porque arrancaran los trabajos de campo en las Canarias Occidentales debe tenerse en cuenta que de la partida de 20.800 pesetas, 16.800 pasaron a publicaciones de la Comisaría General, y sólo estas 4.000 pesetas se destinaron a nuevas excavaciones (AGA 296, 16-11-1942). El dinero debía justificarse antes de ser gastado con facturas de Tenerife y La Gomera, que parecen haber sido recibidas el 23 de enero de 1943 (AGA 296).

Ni Álvarez Delgado, ni Serra Ràfols eran arqueólogos de campo, pero sin informar a Martínez Santa-Olalla, entre los dos acordaron que el trabajo de momento lo comenzase a realizar otro maestro, Luis Diego Cuscoy, quien comenzó esa navidad de 1942 las excavaciones en el Risco del Perro (La Matanza) y las continuó en el Barranco de Guayonje (Tacoronte) (FLDC, 31-1-1943; Mederos y Escribano, 2011, 248251; Navarro y Clavijo, 2011).

\section{CONCLUSIONES}

En ocasiones, la investigación arqueológica depende significativamente de las trayectorias políticas de sus protagonistas. Mas excepcional es cuando determinados acontecimientos políticos afectan significativamente a la investigación arqueológica, en este caso de Canarias, y por extensión a la incipiente línea de trabajo desarrollada entonces por la Comisaría General de Excavaciones Arqueológicas para España, en circunstancias políticas extremas como fue la Segunda Guerra Mundial.

Tanto en las reuniones entre Serrano Suñer con Ribbentrop en Berlín el 16 y 17 de septiembre de 1940, actuando como traductor Tovar, como en la entrevista de
Franco con Hitler en Hendaya el 23 de octubre, donde también asistieron Tovar y Serrano Suñer, aunque no en el vagón de la entrevista, la principal reivindicación alemana había sido una isla de Canarias para disponer de una gran base aérea y marítima antes de enfrentarse a Estados Unidos y tratar de controlar completamente el hemisferio norte, a cambio de lo cual Hitler estaba dispuesto a ceder el Marruecos francés a España.

La reacción de Serrano Suñer y Tovar, a pesar de ser partidarios de una intervención militar junto a Alemania e Italia, fue un rechazo absoluto. A las dudas del general Franco de intervenir con las potencias del Eje después del fracaso de Mussolini en Grecia y los Balcanes, se sumó la necesidad de defender el papel de las Islas Canarias como una parte integrante de España y del futuro Imperio español.

No debe olvidarse que Tovar no sólo fue un firme defensor de El Imperio de España (1936 y 1941), sino que fue quien redactó la carta donde Franco reclamaba a Hitler sus reivindicaciones territoriales sobre el imperio colonial francés en África, que no sólo no admitía ningún tipo de pérdidas territoriales, sino que exigía la expansión del nuevo Imperio español que, como se recogía en Reivindicaciones de España (Areilza y Castiella, 1941), exigía como «indispensables» el Peñón de Gibraltar, el Oranesado argelino, Tánger, el Protectorado francés en Marruecos y zonas del Golfo de Guinea que «nos arrebataron» Inglaterra y Francia. «Sólo de esa manera España llegará a ser una de las cuatro, cinco o seis grandes unidades que (...) están llamadas a gobernar el mundo de este siglo» (Tovar, 1941, 106-107).

La decisión propagandística que se consideró más apropiada por parte de Serrano Suñer, Ministro Presidente de la Junta Política y Delegado Nacional de Prensa y Propaganda de F.E.T. y de las J.O.N.S., y por Antonio Tovar, Subsecretario de Prensa y Propaganda, fue celebrar una gran Exposición de las Islas Canarias en Madrid, decidida el 18 de febrero de 1941, para su inmediata apertura sólo 3 meses después, entre el 15 de mayo y el 15 de junio de ese mismo año.

Obviamente, las razones últimas de esta gran exposición propagandística eran alto secreto porque derivaban de las exigencias militares de Hitler, y se trató de vender como un «hermoso acto de reparación a las Islas olvidadas» en palabras del Comisario Provincial, Jiménez Sánchez.

Para anunciar y preparar cuanto antes la exposición se organizó un viaje a las Islas Canarias entre el 7 y el 18 de marzo, encabezado por Dionisio Ridruejo, Director General de Propaganda, en la que también participaron Martínez Santa-Olalla como responsable de la sala de Historia y Pérez de Barradas de la sala de Folklore.

Para la organización de las salas de Historia y Folklore se nombraron como responsables de la organización en las islas a los dos Comisarios Provinciales de Excavaciones Arqueológicas, Sebastián Jiménez Sánchez y Dacio Darias y Padrón, los cuales visitaron yacimientos y museos en ambas islas con Martínez 
Santa-Olalla, Pérez de Barradas y el fotógrafo Valmitjana, y como resultado se consolidó la relación personal de ambos con Martínez Santa-Olalla.

Sabemos que también hubo un segundo viaje en abril del director de la exposición y otros miembros, si bien no volvieron a viajar Martínez Santa-Olalla ni Pérez de Barradas, que por lo menos visitó La Palma, La Gomera y El Hierro, acompañados por Darias y Padrón junto al fotógrafo.

La organización de la exposición muestra como la realidad acabó imponiéndose sobre los proyectos propagandísticos. El primer problema eran los costes en una situación económica muy difícil, donde el grueso de la inversión del nuevo Estado se destinaba al ejército. El gran número de actividades previstas implicaban el traslado de piezas; el adelanto de dinero para la construcción de maquetas, dioramas, reproducciones, vaciados, acuarelas y fotografías; el viaje de los conferenciantes, de los actores teatrales, de los participantes en los actos musicales que incluían orquesta de cámara, rondallas, grupos de baile, coros y comparsas, grupo de lucha canaria, etc. El segundo problema fue que se trató de celebrar en el Pabellón de Exposiciones Regionales, el cual se estaba construyendo en la Plaza de España de Madrid y no consiguió terminarse a tiempo.

El proyecto sólo consiguió en 1941 la apertura de una Exposición de Carteles murales anunciadores de la Exposición de las Islas Canarias, que se inauguró el 25 de junio en el Ateneo de Madrid, seguida ya el 4 de noviembre de 1941 de una exposición de fotografías de las Islas Canarias inaugurada en el Círculo de Bellas Artes de Madrid, con una selección de las 5.000 fotos realizadas por Augusto Valmitjana para la exposición. Se «culminó» con un suplemento monográfico en el diario Arriba, órgano de Falange, el 16 de enero de 1942. Aún un año después, el 15 de julio de 1942, se seguía hablando «de la proyectada Exposición Canarias».

Aunque el organigrama básico de la Comisaría General de Excavaciones Arqueológicas se estableció en Madrid desde el 1 de mayo de 1939, careció de financiación para la realización de excavaciones arqueológicas hasta 1942, boicoteada por el Ministro de Educación Nacional y el Director General de Bellas Artes como ha demostrado Gracia (2009).

No obstante, la detallada documentación de las Islas Canarias muestra como el organigrama comenzó a funcionar desde 1939 a escala provincial, aunque se carecía de financiación. Aprovechando la estancia de José Pérez de Barradas en Las Palmas, entre septiembre de 1938 y enero de 1939, se creó un estrecho lazo con Jiménez Sánchez, periodista, maestro, funcionario de Obras Públicas desde 1934, Delegado Provincial de Educación Popular y Jefe de Censura y Publicaciones de Falange Española Tradicionalista y de las J.O.N.S. Esto le permitió ser nombrado Comisario Insular de Excavaciones Arqueológicas en Gran Canaria, el 15 de enero de 1940, cuyas competencias se ampliaron como Comisario Provincial de Excavaciones Arqueológicas desde el 29 de mayo de 1940.
Aunque carecía de cualquier experiencia arqueológica de campo, ya en agosto de 1940 realizó su primera excavación en dos túmulos junto al Roque Antigafo o Partido, en el puerto de Las Nieves de Agaete, hallados por soldados, cuando se realizaban obras de fortificación ante el riesgo de invasión aliada. En 1941 su investigación se orientó a los grabados rupestres del Barranco de Balos (Agüimes, Gran Canaria) después de la publicación del libro de Wölfel (1940a).

Otro aspecto que priorizó Martínez Santa-Olalla fue financiar excavaciones donde contaba con la ayuda adicional de las instituciones locales. En el caso de Gran Canaria, consiguió el compromiso del Presidente del Cabildo Insular, Antonio Limiñana López, de aportar 10.000 pesetas anuales cuando una cantidad similar se librase por la Comisaría General de Excavaciones Arqueológicas, aunque al final el dinero que se aportó desde Madrid fue 6.000 pesetas. El objetivo de Jiménez Sánchez era continuar la excavación realizada por miembros de El Museo Canario entre enero y abril de 1934 en los túmulos de La Guancha y El Agujero y de un conjunto de casas anexo (Jiménez Sánchez, 1941).

En el caso de las Canarias Occidentales, la elección de Dacio Darias y Padrón, militar retirado, maestro, periodista, fundador de la Revista de Historia y Comandante Militar de la isla de El Hierro después de estallar la Guerra Civil, su elección fue resultado de su amistad con Jiménez Sánchez que lo recomendó a Martínez Santa-Olalla y a Pérez de Barradas. Nombrado Comisario Insular de Excavaciones Arqueológicas de Tenerife cuatro meses después que Jiménez Sánchez, al ascender a éste a Comisario Provincial a finales de mayo, enterado Darias y Padrón, lo solicitó a Martínez Santa-Olalla que lo autorizó a inicios de junio, pues el objetivo de Darias era también trabajar en los grabados de El Julan, de su isla natal de El Hierro.

En Tenerife, Martínez Santa-Olalla gestionó la posible adquisición de las colecciones arqueológicas del Museo Villa Benitez para formar un Museo Arqueológico en Tenerife ya en 1940, que no culminó porque no se quiso separar para su venta las colecciones de Ciencias Naturales, y ese mismo año, Darias, con el apoyo de Martínez Santa-Olalla que escribió al Gobernador Civil, y éste a los alcaldes, se hizo un cuestionario para un Catálogo Artístico y Arqueológico de la Provincia.

También Martínez Santa-Olalla había conseguido el compromiso del Presidente del Cabildo de Tenerife, Francisco La-Roche, para aportar 10.000 pesetas adicionales al dinero de la Comisaría General de Excavaciones Arqueológicas, aunque sólo pudo destinar finalmente 6.000 pesetas para excavar cuevas en Tenerife. La posibilidad de disponer de esta financiación adicional por el Cabildo Insular de Tenerife forzaba a Darias y Padrón a excavar en la isla, pero donde realmente tenía interés de investigar era los grabados rupestres de El Julan de El Hierro. Por otra parte, tenía 61 años y carecía de cualquier experiencia previa en arqueología.

Al no afrontar las excavaciones previstas durante el verano de 1942, Martínez Santa-Olalla le obligó a elegir 
entre sus dos personas más próximas en la Revista de Historia y en el Comité que había preparado la Exposición de las Islas Canarias, Elías Serra Ràfols, Decano de Filosofía y Letras y Catedrático de Historia de España de la Universidad de La Laguna, o bien Juan Álvarez Delgado, Catedrático de Latín de Instituto, Profesor interino de la Facultad de Filología Clásica de la Universidad de La Laguna, Subjefe Provincial del Movimiento y Delegado Provincial de Prensa y Propaganda de $\mathrm{Fa}$ lange Española Tradicionalista y de las J.O.N.S., que fue al final la persona elegida por Darias y Padrón. Ninguno de los dos eran arqueólogos de campo, pero entre los dos acordaron que las excavaciones las comenzase a realizar el maestro Luis Diego Cuscoy.

\section{AGRADECIMIENTOS}

Queremos agradecer la permanente amabilidad de Salvador Quero por poder consultar la documentación del Archivo Julio Martínez Santa-Olalla (ASO) y de Alberto González con el Fondo Documental Pérez de Barradas (FD2005), ambos en el Museo de los Orígenes de Madrid. A Daniel García Pulido y José Perera López sus atenciones al consultar el Fondo Dacio Darias y Padrón (DDP) en la Universidad de La Laguna. A Daniel Gozalbo por su orientación en el Archivo General de la Administración (AGA). Y Juana Hernández Suárez y al Patronato del Museo Arqueológico del Puerto de la Cruz el poder estudiar la documentación del Fondo Luis Diego Cuscoy (FLDC).

\author{
Prof. Dr. Alfredo Mederos Martín \\ Dpto. de Prehistoria y Arqueología \\ Facultad de Filosofía y Letras \\ Universidad Autónoma de Madrid \\ Campus de Cantoblanco \\ 28049 Madrid \\ alfredo.mederos@uam.es
}

\section{BIBLIOGRAFÍA}

ÁLVAREZ DELGADO, J., 1941: «Los aborígenes de Canarias ante la lingüística», Actas y Memorias de la Sociedad Española de Antropología, Etnografia y Prehistoria, 16, 276-290.

ÁLVAREZ DELGADO, J., 1945: «Ecero. Notas lingüísticas sobre El Hierro. Los lugares rituales del Hierro», Revista de Historia Canaria, 11 (72), 408-416.

ÁlVAREZ DELGADO, J., 1948: «Los Santillos de los Antiguos. Isla del Hierro (Canarias)», Revista de la Real Sociedad Geográfica, 84 (1-6), 196-204.

AREILZA, J.Mª de y CASTIELLA, F.Ma., 1941: Reivindicaciones de España, Madrid.

AYALA ZAMORA, J., 1999: Datos biográficos de D. Dacio Victoriano Darias y Padrón (1880-1960), herreño, militar, maestro, historiador, Tenerife.

BERTHELOT, S., 1839: Histoire Naturelle des Îles Canaries. Tome I. Partie 2. Miscellanées canariennes, Béthune et Plon, Paris.
BERTHELOT, S., 1839/1980: Primera estancia en Tenerife (1820-1830), Tenerife.

BOSCH MILLARES, J., 1941: «Estigmas sifilíticos entre los Guanches», Actas y Memorias de la Sociedad Española de Antropología, Etnografia y Prehistoria, 16, 249-261.

BOWEN, W.H., 2000: Spaniards and Nazi Germany: collaboration in the new order, Columbia, Ms.

CABANAS ERAUSKI, J., 1941: Exposición de las Islas Canarias, Madrid-1941, Delegación Nacional de Prensa y Propaganda de F.E.T. y de las J.O.N.S., Madrid.

CABRERA ACOSTA, M.A., 1985: La represión franquista en El Hierro (1936-1944), Abora, 1. La Laguna.

CHIL y NARANJO, G., 1876: Estudios históricos, climatológicos y patológicos de las Islas Canarias, Primera Parte, Historia. I, Ernest Leroux Editeurs-Isidro Miranda Impresor, Paris-Las Palmas.

CHIL y NARANJO, G., 1880: Estudios históricos, climatológicos y patológicos de las Islas Canarias. II, Imprenta de la Atlántida. Las Palmas-Ernest Leroux Libraires-Editeurs, Paris.

CHIL y NARANJO, G., 1891: Estudios históricos, climatológicos y patológicos de las Islas Canarias. III. Imprenta de La Atlántida, Las Palmas-Ernest Leroux Libraires-Editeurs, Paris.

DARIAS y PADRÓN, D.V., 1929/1980: Noticias generales históricas sobre la isla del Hierro. Una de las Canarias, Tenerife.

DARIAS y PADRÓN, D.V., 1934: Breves nociones sobre la historia general de las Islas Canarias, La Laguna.

DARIAS y PADRÓN, D.V., 1952: «La Frontera (Hierro). El Julan. 2-X-1940», Noticiario Arqueológico Hispánico, 1 (1-3), 1952 (1953), 179.

DIAZ-ANDREU, M. y RAMÍREZ, M.E., 2001: «La Comisaría General de Excavaciones Arqueológicas (1939-1955). La administración del patrimonio arqueológico en España durante la primera etapa de la dictadura franquista», Complutum, 12, 325-343.

FARRUJIA, A.J. y ARCO, Ma.C. del, 2002: «El primer poblamiento humano de Canarias según la concepción 'españolista' de José Pérez de Barradas», Achaia, 2 (2), 60-70.

GARCÍA ORTEGA, J., 1935: El hecho de la Hispanización de Canarias, La Laguna.

GODA, N.J.W., 1991: Germany and Northwest Africa in the Second World War: Politics and Strategy of Global Hegemony, PhD. Thesis, North Carolina University.

GODA, N.J.W., 1998: Tomorrow the World: Hitler, Northwest Africa, and the Path toward America, William-Ford Texas A\&M University Military History Series, College Station, TX.

GODA, N.J.W., 1998/2002: Y mañana el mundo. Hitler, África noroccidental y el camino hacia América, Madrid.

GRACIA ALONSO, F., 2009: La arqueología durante el primer franquismo (1939-1956), Barcelona.

HERNÁNDEZ BENÍTEZ, P., 1945: «Inscripciones y grabados rupestres del barranco de Balos», El Museo Canario, 6 (15), 3-14.

HERNÁNDEZ BENÍTEZ, P., 1955: «Dos inscripciones epigráficas Latino-Romanas», III Congreso Nacional de Arqueología (Galicia, 1953), 182-186, Zaragoza. 
HERNÁNDEZ BENÍTEZ, P., 1958: Telde (sus valores arqueológicos, históricos, artísticos y religiosos), Telde.

IZQUIERDO PÉREZ, E., 2005: Periodistas canarios. Siglos XVIII al XX. Propuesta para un diccionario biográfico y de seudónimos. I-III, La Laguna.

JIMÉNEZ DÍEZ, J.A. y MEDEROS, A., 2001: Comisión de Antigüedades de la Real Academia de la Historia. Baleares. Canarias. Melilla. Gibraltar. Extranjero. Catálogo e Índices, Madrid.

JIMÉNEZ SÁNCHEZ, S., 1936-40: «Dos túmulos guanches en Agaete (Gran Canaria)», Atlantis. Actas y Memorias de la Sociedad Española de Antropología, Etnografia y Prehistoria, 15, 169-170.

JIMÉNEZ SÁNCHEZ, S., 1941: «Embalsamamientos y enterramientos de los 'canarios' y 'guanches', pueblos aborígenes de las Islas Canarias», Actas y Memorias de la Sociedad Española de Antropología, Etnografia y Prehistoria, 16, 129-145.

JIMÉNEZ SÁNCHEZ, S., 1942: «Vestigios arqueológicos canarios. Cuevas y Tagóror de la Montaña de Cuatro Puertas (Isla de Gran Canaria)», Revista de Historia Canaria, 8 (57), 30-37.

JIMÉNEZ SÁNCHEZ, S., 1952a: «Telde (Gran Canaria). El Roque. 1-VII-1940», Noticiario Arqueológico Hispánico, 1 (1-3), 1952 (1953), 182.

JIMÉNEZ SÁNCHEZ, S., 1952b: «San Nicolás (Gran Canaria). Los Caserones. 30-IX-1940», Noticiario Arqueológico Hispánico, 1 (1-3), 1952 (1953), 181.

LAÍN ENTRALGO, P., 1976: Descargo de conciencia (19301960), Breve biblioteca de respuesta, 49, Barcelona.

MEDEROS, A. y ESCRIBANO, G., 2011: Julio Martínez Santa-Olalla, Luis Diego Cuscoy y la Comisaría Provincial de Excavaciones Arqueológicas de las Canarias Occidentales (1939-1955), Canarias Arqueológica Monografías, 5, Sevilla-Tenerife.

NAVARRO MEDEROS, J.F., 2008: «Unidad de origen y unidad de destino: José Pérez de Barradas y la arqueología de las Islas Canarias», en E. de CARRERA y A. MARTÍN FLORES (eds.), Arqueología. América. Antropología. José Pérez de Barradas 1897-1981. Catálogo de Exposición (Madrid, 2008), 369-381, Madrid.

NAVARRO, J.F. y CLAVIJO, M.A., 2011: «44 años de arqueología canaria», en J.F. NAVARRO y M.A. CLAVIJO (eds.): 44 años de arqueología canaria. Textos escogidos de Luis Diego Cuscoy, 9-55, La Laguna.

PADRÓN MACHÍN, J., 1983: Noticias relacionadas con la Historia de la Isla del Hierro, Tenerife-Valverde

PÉREZ DE BARRADAS y ÁLVAREZ DE EULATE, J., 1939: Estado actual de las investigaciones prehistóricas sobre Canarias. Introducción al estudio de la arqueología canaria. Memoria acerca de los estudios realizados en 1938 en el 'El Museo Canario', Las Palmas.

PÉREZ DE BARRADAS y ÁLVAREZ DE EULATE, J., 1944: El Museo Canario. Catálogo de la colección de cerámica, y objetos arqueológicos (Salas Grau y Navarro), Publicaciones de El Museo Canario, Anexo, 1, Las Palmas.

RAMÍREZ SÁNCHEZ, M.E., 2000: «Aproximación historiográfica a la investigación arqueológica en Canarias: la Comisaría Provincial de Excavaciones Arqueológicas de Las Palmas (1940-1969)», en V. OLIVEIRA JORGE (ed.), $3^{\circ}$ Congresso de Arqueologia Peninsular (Vila Real, 1999), 417-429, Porto.

RAMÍREZ SÁNCHEZ, M.E., 2002: «Sebastián Jiménez Sánchez y la investigación arqueológica en la provincia de Las Palmas (1940-1969): un balance historiográfico», en F. MORALES PADRÓN (ed.), XIV Coloquio de Historia Canario-Americana (Las Palmas, 2000), 549-566, Las Palmas.

RAMÍREZ SÁNCHEZ, M.E., 2004: «La administración del patrimonio arqueológico en la provincia de Las Palmas (1940-1969)», en A.J. FARRUJIA y Mª.C. DEL ARCO (eds.), Arqueología, raza y gestión. Estudios historiográficos, Eres, 12, 123-142.

RÉGULO PÉREZ, J., 1953: «Don Dacio V. Darias y Padrón, Académico correspondiente de la Historia», Revista de Historia Canaria, 19 (101-104), 335-340.

RODRÍGUEZ JIMÉNEZ, J.L., 2000: Historia de Falange Española de las JONS, Madrid.

ROS AGUDO, M., 2008: La gran tentación. Franco, el Imperio colonial y los planes de intervención en la Segunda Guerra Mundial, Barcelona.

SERRANO SUÑER, R., 1973: Entre Hendaya y Gibraltar, Barcelona.

SERRANO SUÑER, R., 1977: Entre el silencio y la propaganda, la Historia como fue. Memorias, Barcelona.

TORRIANI, L., 1592: Descrittione et historia del Regno del Isole Canarie già dette Fortunate con el parere delle loro fortificatione, Manuscrito. Biblioteca de la Universidade do Coimbra.

TORRIANI, L., 1592/1940: Die Kanarische Inseln und ihre Urbewohner, eine unbekannte Bilderhandschrift vom Jahre 1590, im italienischen Urtext und in deutscher Uebersetzung, D.J. Wölfel (ed.), Quellen und Forschungen zur Geschichte der Geographie und Völkerkunde, 6, Leipzig.

TOVAR LLORENTE, A., 1936/1941: El Imperio de España, Madrid.

TOVAR LLORENTE, A., 1986: «De Berlín a Valladolid», El País, 18-7-1986, 14-15, Madrid.

TUSELL GÓMEZ, J., 1995: Franco, España y la II Guerra Mundial. Entre el Eje y la neutralidad. Memoria Viva, 1, Madrid.

WÖLFEL, D.J., 1940a: Leonardo Torriani. Die Kanarischen Inseln und ihre Urbewohner. Eine unbekannte Bilderhandschrift vom Jahre 1590, Quellen und Forschungen zur Geschichte der Geographie und Völkerkunde, 6, Leipzig.

WÖLFEL, D.J., 1940b: «Vorläufige Mitteilungen zu den kanarischen Siegeln und Inschriften», en L. TORRIANI, Die Kanarischen Inseln und ihre Urbewohner. Eine unbekannte Bilderhandschrift vom Jahre 1590, Quellen und Forschungen zur Geschichte der Geographie und Völkerkunde, 6, 304-310, Leipzig.

WÖLFEL, D.J., 1940b/1942: «Ensayo provisional sobre los sellos e inscripciones canarios. Apéndice III de la edición de Torriani, por D.J. Wölfel», Revista de Historia Canaria, 8 (58), 106-107 y 8 (59), 151-155. 